Eur J Pharmacol. 2009 December 25; 625(1-3): 41-54. doi:10.1016/j.ejphar.2009.09.067.

\title{
Immunotherapy of cancer
}

\author{
Hossein Borghaeia ${ }^{a}$ Mitchell R. Smith ${ }^{a}$, and Kerry S. Campbell ${ }^{b}$ \\ aDepartment of Medical Oncology, Fox Chase Cancer Center, 333 Cottman Avenue, Philadelphia, \\ PA 19111 USA \\ bInstitute for Cancer Research, Fox Chase Cancer Center, 333 Cottman Avenue, Philadelphia, PA \\ 19111 USA
}

\begin{abstract}
Major advances have been made in the field of immunology in the past two decades. A better understanding of the molecular and cellular mechanisms controlling the immune system, has opened the door to many innovative and promising new cancer therapies that manipulate the immune response. For instance, toll-like receptor agonists have been shown to boost immune responses toward tumors. Also, a wide array of cell-based immunotherapies utilizing T cells, NK cells, and dendritic cells have been established. Furthermore, a rapidly expanding repertoire of monoclonal antibodies is being developed to treat tumors, and many of the available antibodies have demonstrated impressive clinical responses. Here, we examine some of these immunotherapeutic approaches currently in use or testing to treat cancer, and we examine available evidence with regards to mechanism and efficacy of these treatments.
\end{abstract}

\section{Keywords}

Immunotherapy; cancer; monoclonal antibody; cell-based therapy; toll-like receptors

\section{Introduction}

For decades, primary cancer treatments have incorporated both chemotherapeutic agents and ionizing radiation to eliminate the bulk of tumor mass. While many of these therapies have offered substantial benefit and some cures, the incidence of tumor relapse is a significant problem that results from the development of drug resistance mechanisms in a portion of the tumor cells. Therefore, additional therapeutic approaches to eliminate these resistant tumor cells must be established.

One appealing alternative strategy is therapy designed to harness the immune system to induce a potent anti-tumor response. Historically, the first successful immunotherapy to treat cancer involved the use of toxins from Streptococcus erysipelatis and Bacillus prodigious by William Coley in the 1890's (Coley, 1991). More recently, the development of vaccines to tumorcausing hepatitis $\mathrm{B}$ virus and papilloma virus are contributing significantly to preventing cancer

(C) 2009 Elsevier B.V. All rights reserved.

Corresponding Author: Kerry S. Campbell, Ph.D. Institute for Cancer Research Fox Chase Cancer Center 333 Cottman Avenue Philadelphia, PA 19111-2497 USA phone: 215.728.7761, fax: 215.728.2412 kerry.campbell@fccc.edu. hossein.borghaei@fccc.edu, Mitchell.Smith@fccc.edu

Publisher's Disclaimer: This is a PDF file of an unedited manuscript that has been accepted for publication. As a service to our customers we are providing this early version of the manuscript. The manuscript will undergo copyediting, typesetting, and review of the resulting proof before it is published in its final citable form. Please note that during the production process errors may be discovered which could affect the content, and all legal disclaimers that apply to the journal pertain. 
in a large portion of the human population (Blumberg, 1997; Rogers et al., 2008). Since our understanding of basic immune mechanisms has expanded substantially, a wide array of immune pathways have been identified as attractive targets to promote anti-tumor responses in cancer patients.

Many immune cell types influence tumor growth in humans. The immune system is comprised of both innate cells that mediate immediate, short-lived responses [monocytes, macrophages, dendritic cells, and natural killer (NK) cells] and adaptive cells that develop long-lived responses and memory ( $\mathrm{T}$ cells and $\mathrm{B}$ cells). The functions of these cells in response to cancer are schematized in Figure 1. The innate cells provide the earliest responses by releasing cytokines, directly lysing abnormal cells (NK cells) or capturing debris from dead cells (monocytes, macrophages, and dendritic cells) to present peptide fragments of specific foreign antigens to $\mathrm{T}$ cells in the context of major histocompatibility complex (MHC) molecules. The adaptive $\mathrm{T}$ and $\mathrm{B}$ cells generate antigen-specific responses that are delayed by several days, since minor subpopulations expressing antigen-specific receptors must proliferate and differentiate to generate a multitude of competent and activated effector cells. These proliferation and differentiation events are promoted by inflammatory cytokines [interferon (IFN)- $\gamma$, interleukin (IL)-12] produced by the activated innate immune cells or T cells. T cells can be divided into two major subsets consisting of $\mathrm{CD} 8^{+}$cytolytic (CTL) and CD4 ${ }^{+}$helper (Th) cells that can directly lyse tumor cells or release immunomodulatory cytokines, respectively, while $\mathrm{B}$ cells generate a humoral response by secreting antigen-specific immunoglobulin (Ig). Human CTL and Th cells express $\alpha / \beta$ antigen receptors (TCR) that recognize foreign antigenic peptides presented in the contexts of MHC class I (HLA-A, -B, and $-\mathrm{C}$ ) or class II (HLA-DR, -DP and -DQ), respectively. Th cells can be subdivided based upon their capacities to secrete various cytokines into: Th1 cells (secrete type-1 cytokines, especially IFN- $\gamma$ and IL-2, which are considered inflammatory), Th2 cells (secrete type-2 cytokines, including IL-4, IL-5, and IL-13, which are associated with allergic responses), and Th17 cells (secrete IL-17 and IL-22, which can cause inflammation in skin and mucosal surfaces and can also promote autoimmune responses). Additional relevant $\mathrm{T}$ cell subpopulations include invariant NK-like T (iNKT) cells, $\gamma / \delta \mathrm{T}$ cells, and regulatory T (Treg) cells, and the cytokines produce by these $\mathrm{T}$ cell subsets are summarized in Figure 2. The iNKT cells provide a rapid and potent source of IL- 4 and IFN- $\gamma$, which is triggered through recognition of glycolipids presented by MHC-like CD1d molecules by their invariant $\alpha / \beta$ TCR. Alternatively, the $\gamma / \delta$ T cells express a $\gamma / \delta$ TCR that is triggered by recognition of a variety of ligands, which appear to be recognized directly in an Ig-like manner (Born et al., 2007). In contrast, Treg cells have been found to infiltrate tumors and draining lymph nodes, where they can repress tumor-specific CTL responses through a variety of mechanisms, including production of the immunosuppressive cytokines IL-10 and transforming growth factor (TGF)$\beta$ (Allan et al., 2008). Tumor-associated macrophages and myeloid-derived suppressor cells can also release immunosuppressive cytokines within the tumor microenvironment to inhibit dendritic cells functions and reportedly promote angiogenesis and tumor growth (Melief, 2008;Pittet, 2009).

The effectiveness of an anti-tumor immune response can be compromised by the immunosuppressive impacts of either cytotoxic chemotherapeutic drugs or cytokines produced within the tumor microenvironment [especially IL-10, TGF- $\beta$, IL-6, and prostaglandin E2]. Recent findings indicate that some tumors establish a protective immune-privileged environment by promoting the production of type-2-related cytokines (IL-4, IL-5, IL-6, IL-10, IL-13, and IL-21). The type-2 cytokines suppress the production of inflammatory type-1related cytokines (IFN- $\gamma$, IL-12, IL-2) to thereby blunt the adaptive anti-tumor immune response (Becker, 2006). In fact, polarization of the immune response toward type- 2 cytokine production has been associated with progression of a number of tumor types (Becker, 2006). Additional mechanisms of immune evasion by tumor cells include minimal expression or 
shedding of tumor-associated antigens and shedding of ligands for activating receptors, such as the ULBP2, MICA and MICB ligands recognized by the NK cell receptor NKG2D, thereby preventing its function (Salih et al., 2006; Salih et al., 2002; Waldhauer and Steinle, 2006).

The field of cancer immunotherapy covers a vast array of manipulations to provoke immune responses toward tumors in both humans and animals. Therefore, we will only touch upon certain techniques that have promising or proven clinical value in treating cancer in patients. In the following discussion, we will focus on advances in the use of Toll-like receptor agonists, cellular immunotherapies, and antibody-based immunotherapies.

\section{Toll-like receptor agonists}

The family of Toll-like receptors (TLR) recognize specific molecular patterns found on byproducts of various pathogens, especially bacteria. Agonists for TLR2, TLR3, TLR4, and TLR9 are particularly attractive for boosting inflammatory innate immune responses to treat cancer. These stimulants have been historically referred to as "adjuvants" to boost vaccine therapies, and most of their effects are due to boosting the activity of myeloid cells (macrophages, monocytes, and dendritic cells). TLR2 ligands include muramyl peptides, peptidoglycans, and lipoteichoic acids, while polyinosinic acid:cytidylic acid (poly I:C) is a synthetic double stranded RNA that serves as a classic agonist of TLR3. Lipopolysaccharide (LPS) is the well-known agonist for TLR4, which has been identified as the "hemorrhage producing fraction" from the Gram negative bacteria that stimulated antitumor effects in Coley's toxin (Garay et al., 2007). Bacillus Calmette-Guérin (BCG) contains peptidoglycans from the cell wall of mycobacteria, which is an agonist for both TLR2 and TLR4 that has been used for decades to stimulate immune responses in treating bladder cancer (Garay et al., 2007). TLR9 can be stimulated with unmethylated CpG DNA sequences that are significantly more prevalent in bacteria than vertebrates (Jahrsdorfer and Weiner, 2008), and this may account for some non-specific antisense oligonucelotide effects. TLR2 or TLR4 agonists stimulate macrophages and dendritic cells to produce inducible nitric oxide synthetase (iNOS) and numerous proinflammatory cytokines and chemokines, including IL-1, IL-6, IL-8, IL-10, IL-12, IL-23, TNF- $\alpha$, MIP1 $\alpha$, and MIP1 $\beta$ (Garay et al., 2007). On the other hand, plasmacytoid dendritic cells are selectively stimulated by the TLR3 agonist, poly I:C, to secrete IFN- $\alpha$ and IFN- $\beta$, which are potent activators of NK cells and CTL. The use of CpG analogs to stimulate TLR9 on dendritic cells can induce production of IL-12, IFN- $\alpha$ and IFN- $\beta$ (Jahrsdorfer and Weiner, 2008). Although not detailed here, a wide array of compounds have been developed as TLR agonists that are currently being tested to treat cancer. It is important to note, however, that TLR agonists can also stimulate the growth and survival of some tumors (Rakoff-Nahoum and Medzhitov, 2009), so they may only be therapeutically useful under defined conditions.

\section{Cellular immunotherapies}

\subsection{T cells}

In view of their importance in establishing adaptive immune responses, many groups have attempted to activate a patient's own (autologous) tumor-reactive $\mathrm{T}$ cells by culturing them with IL-2 and other cytokines and reinjecting these cells to treat cancer. Such methods are designed to increase the number of reactive $\mathrm{T}$ cells and provide long-term immune protection with minimal autoimmune responsiveness. Importantly, however, the need for specialized cell culture facilities and time intensive cell preparation requirements have limited their use. Success of adoptive transfer has been improved by using chemotherapy and/or total body irradiation to achieve lymphodepletion prior to cell infusion, as well as IL-2 infusions post infusion. Although attempted under a wide variety of conditions, adoptive transfer of ex vivo activated autologous $\mathrm{T}$ cells has had limited effectiveness in treating leukemia (Curti et al., 1998; Morgan et al., 2006; Schultze et al., 2001), but some success in treating melanoma (Oble 
et al., 2009). In contrast to bacterial or viral pathogens, tumor cells generally lack "foreign" antigens, and therefore, $\mathrm{T}$ cell reactivity is directed toward peptide antigens derived from altered or over-expressed gene products. The ex vivo expansion and reintroduction of tumorinfiltrating lymphocytes (TILs) is a particularly attractive approach, since TILs can contain tumor-specific T cell populations (Disis et al., 2009; Oble et al., 2009). CD4 ${ }^{+}$Th cells have also been found to be more effective than $\mathrm{CD} 8^{+} \mathrm{CTL}$ in adoptive transfer therapies (PerezDiez et al., 2007). T cell reactivity toward several antigens over-expressed in melanoma (such as MAGE-6, Melan-A/MART-1, NY-ESO-1, and gp100) has been established from the characterization of TILs (Oble et al., 2009). These and other antigens are being studied as potential tumor vaccines. Some success has also been observed using genetically engineered T cells in which an antigen-specific antigen receptor has been introduced by retrovirus (Morgan et al., 2006).

Dendritic cells are potent antigen-presenting cells that serve as critical initiators of $\mathrm{T}$ celldependent immune responses. Therefore, they have been widely studied as potential vectors that can be loaded with peptide antigens for presentation to $\mathrm{T}$ cells and stimulate adaptive immunity (Disis et al., 2009; Melief, 2008). In particular, many groups have loaded with peptides derived from characterized tumor-associated antigens or material from a patient's tumor to introduce cancer vaccines (Disis et al., 2009; Kuwabara et al., 2007; Melief, 2008; Nagayama et al., 2003; Yamanaka, 2009).

Allogeneic hematopoietic stem cell transplantation has been widely used to exploit the $\mathrm{T}$ cellmediated allogeneic immune response in cancer immunotherapy, especially for treating highrisk leukemia patients, where graft-versus-leukemia responses can be beneficial. In allogeneic $\mathrm{T}$ cell responses, the donor $\mathrm{T}$ cells respond to the MHC molecules of the recipient as foreign antigens. While allogeneic $\mathrm{T}$ cell responses mediate the graft-versus-leukemia effect, the development of $\mathrm{T}$ cell-mediated graft-versus-host disease can be a serious complication of hematopoietic stem cell transplantation that often requires lifelong immunosuppressive therapy and can be fatal. As mentioned above, ex vivo-activated autologous T cell immunotherapies are designed to avoid autoimmune responses, but these approaches have generated only limited success in treating cancer, and graft-versus-host disease can still occur in the autologous context. The failure of adoptive $\mathrm{T}$ cell therapies can be attributed, at least in part, to ineffective homing of the activated $\mathrm{T}$ cells to the tumor site, contamination of $\mathrm{T}$ cell preparations with Treg cells, short-term survival of ex vivo activated $\mathrm{T}$ cells, emergence of antigen-deficient tumor variants, or suppression of $\mathrm{T}$ cell responsiveness by immunosuppressive factors within the tumor microenvironment.

\subsection{NK cells}

The activation of NK cells is regulated by signals derived from a variety of cell surface activating and inhibitory receptors. Activating receptors include the natural cytotoxicity receptors (NCR: NKp30, NKp44 and NKp46), NKG2D, 2B4, NKp80, and DNAM-1. The major control of NK cell activation, however, is mediated by their expression of inhibitory receptors that are specific for class I MHC (MHC-I) molecules, which prevent attack of normal (MHC-I-expressing) cells in the body. Some tumor cells and virus-infected cells avoid recognition by CTL by down-regulating their expression of MHC-I, but these escape mutants consequently become targets for NK cells, since they lack the inhibitory receptor ligands. In this way these inhibitory receptors mediate NK cell tolerance toward normal "self" cells, and their lack of engagement provides the mechanistic basis for recognition and attack of tumors that are lack these "self" ligands, as shown in Figure 3. Killer cell Ig-like receptors (KIR) constitute the major NK cell inhibitory receptors that recognize cognate MHC-I in humans. KIR have evolved in higher mammals as a polymorphic receptor family encoded by distinct genes, each of which can detect a subset of the wide array of polymorphic human MHC-I 
molecules (HLA-A, -B, and-C) (Vilches and Parham, 2002). Expression from individual KIR genes is independently regulated within each NK cell, and during NK cell development, a repertoire of cells is established, in which distinct NK cells stochastically express different members of the KIR family. In order to achieve functional competence, each NK cell must express at least one KIR family member that recognizes at least one of the expressed "self" MHC-I molecules (Anfossi et al., 2006; Cooley et al., 2007). To create further diversity, individuals in the human population inherit different haplotypes of KIR family members (Uhrberg et al., 1997), and most individuals express some KIR that do not recognize their own "self" MHC-I molecules. Due to such diversity, it is possible that a subset of NK cells from one individual will not be tolerized by the MHC-I expressed by another individual, since appropriate ligands are missing for the available inhibitory KIR. This is known as allogeneic NK cell responsiveness, which can occur under conditions of transplantation.

Ruggeri et al. first reported that NK cell alloreactivity, due to KIR-ligand mismatch, can significantly improve survival advantage when introducing haploidentical hematopoietic stem cell transplants to treat acute myeloid leukemia (AML) (Ruggeri et al., 2002). The benefit was observed when the donor expressed KIRs that lacked MHC-I ligands in the recipient. In addition to a beneficial graft-versus-leukemia effect to eliminate the AML, allogeneic NK cells were shown to substantially diminish the incidence of the deleterious T cell-mediated graftversus-host disease. The reduction in graft-versus-host disease in hematopoietic stem cell transplants under conditions of allogeneic NK cell responsiveness appears to be due to elimination of residual antigen presenting cells by the allogeneic NK cells (Ruggeri et al., 2002). While some groups have shown similar benefits from KIR-ligand mismatch in treating AML (Beelen et al., 2005; Giebel et al., 2003; Hsu et al., 2006; Hsu et al., 2005; Leung et al., 2004; Miller et al., 2007a; Yu et al., 2009), others have failed to observe any benefit under allogeneic NK cell transplantation conditions (Davies et al., 2002; Farag et al., 2006). In comparing the methods used, success of the haploidentical KIR-ligand mismatch approach in treating AML required specific conditions: 1) use of haploidentical donors, 2) myeloablative pre-conditioning of the recipient, 3) extensive $\mathrm{T}$ cell depletion of the hematopoietic stem cell graft, and 4) infusion of high numbers of highly purified hematopoietic stem cell.

Umbilical cord blood is also used as a hematopoietic stem cell transplant source for treating hematologic malignancies. Umbilical cord blood contains significantly fewer mature $\mathrm{T}$ cells, which is predicted to be advantageous for reducing the incidence of graft-versus-host disease and expected to favor the benefit of KIR-ligand mismatch. A recent study, however, found that the degree of conditioning of the recipient prior to transplant significantly influenced outcome of umbilical cord blood transplantation (Brunstein et al., 2009). In this study, transplantation of KIR-ligand mismatched umbilical cord blood after reduced intensity conditioning resulted in significantly increased incidence of severe graft-versus-host disease and reduced survival, while the introduction of mismatched umbilical cord blood after myeloablative conditioning did not influence graft-versus-host disease or survival. Therefore, although KIR-ligand mismatch may be advantageous under distinct conditions of hematopoietic stem cell transplantation to treat myelogenous leukemia, it is not universally beneficial and may even be deleterious to patients under other conditions.

Recent work has established improved survival of AML patients that have received hematopoietic stem cell transplants from a donor expressing more of a subset of activating KIR (Cooley et al., 2009). In addition to the inhibitory KIR, other members of this receptor family are known to trigger NK cell activation, although their ligands are currently unknown. While many haplotypes of inherited KIR genes (A haplotypes) contain only one activating KIR (KIR2DS4), others contain more than one activating member (B haplotypes). Cooley et al. have found that hematopoietic stem cell transplants to AML patients from B haplotype donors expressing two or more activating KIR result in reduced relapse and improved overall survival, 
although incidence of chronic graft-versus-host disease was increased (Cooley et al., 2009). These effects were independent of inhibitory KIR-ligand match/mismatch, indicating that the impacts of KIR and their ligands are complex, but can clearly influence outcome and can benefit patients if optimized accordingly.

Further work is clearly necessary to establish the optimal conditions that favor the benefits of $\mathrm{KIR} /$ ligand match/mismatch to promote anti-tumor NK cell responses after hematopoietic stem cell transplantation. As an alternative, the direct adoptive transfer of mature haploidentical NK cells has also been shown to be safe and improve outcome of AML in some patients (Miller et al., 2005a; Passweg et al., 2005). In addition, it may be possible to boost NK cell responsiveness by blocking NK cell inhibitory receptors with antibodies, as has been demonstrated to potentiate ADCC responses in recent in vitro studies (Binyamin et al., 2008). Finally, a highly cytolytic NK-like cell line, named NK-92, may have therapeutic potential if injected into cancer patients after irradiation (Klingemann and Martinson, 2004), and genetic manipulation of this or other NK-like cell lines may further enhance this unique therapeutic approach. Therefore, NK cells remain a viable target for cancer immunotherapy.

\section{Antibody-based immunotherapies}

Antibody-based therapy has emerged as an integral part of effective treatments for a number of malignancies. In the last decade, monoclonal antibodies have become major therapeutic vehicles in the treatment of malignant and nonmalignant diseases. The success of immunebased treatments and an improved understanding of the role of the immune system in cancer development and progression have mapped the road for extensive development of antibodybased therapy.

Paul Ehrlich, a century ago, described the antibody therapy concept to selectively target malignant cells based on the unique expressed determinants profile of the disease (the "magic bullet" hypothesis). The advent of the advanced technology of hybridoma production provided the necessary skills to efficiently produce highly specific monoclonal antibodies (mAb) (Kohler and Milstein, 1975; Kohler and Milstein, 1976). Extensive efforts were taken to apply this technique and to generate mAb for cancer therapy. Many mAb that are currently in use were originally derived from hybridoma-derived murine antibodies (Brekke and Sandlie, 2003). A second generation of engineered antibody was employed, considering the major issue of stimulation of human anti-mouse antibody responses and the inefficient interaction of the murine origin constant region of the antibodies $(\mathrm{Fc})$ with human immune-accessory cells (Mirick et al., 2004). Using an IgG scaffold, humanized and chimeric antibodies were generated by incorporating portions of the murine variable regions into the human IgG backbone (Kim, 2003). Grafting either the entire murine variable regions (chimeric $\mathrm{mAb}$ ) or the murine complementary-determining regions (humanized $\mathrm{mAb}$ ), $\mathrm{mAb}$ are created that contain human Fc domains and preserve their target antigen specificity (Trail et al., 2003). In addition, using molecular engineering techniques, critical human heavy-chain backbone sequences were grafted onto the xenogeneic murine antibody structure, reducing the immunogenicity and providing the important human Fc domain to the resulting antibodies (Khazaeli et al., 1994). Chimeric alteration from fully murine to human $\mathrm{Fc}$ yields prolonged circulation time and more effective cytotoxicity responses. To further increase the power of $\mathrm{mAb}$ and to design antibodies that specifically target and subsequently eliminate cancer cells, large combinatorial antibody libraries of murine, human or synthetic origin were constructed. Efficient in-vitro screening systems now allow bypassing immunization and selecting recombinant antibodies of defined specificity without the need for hybridoma production (Benhar et al., 2000; Hoogenboom, 2002). New forms of antibody modules with different size, flexibility and valency suited for in vivo imaging and therapy have been created using genetic manipulation, recombinant 
production and antibody conjugation techniques (Irving et al., 2001; Worn and Pluckthun, 2001).

\subsection{Mechanisms of tumor cytotoxicity upon antibody binding}

Antibodies may mediate anti-tumor effects by employing a variety of effector mechanisms, including antibody-dependent cellular cytotoxicity (ADCC), complement-dependent cytotoxicity, and inducing or blocking intracellular signals, but the exact mechanisms of action of many of these clinically active antibodies remain unknown. Understanding these events will be key to optimizing antibody engineering and to combination therapy to enhance efficacy. In the following sections we will review some of the available data regarding these functions.

4.1.1 Antibody-dependent cellular cytotoxicity (ADCC)—ADCC is a well-recognized immune effector mechanism in which antigen-specific antibodies direct immune effector cells of innate immunity to the killing of the antigen-expressing cancer cells (Ahmad and Menezes, 1996). This property is dependent upon interactions between cellular Fc receptors (FcR) on immune accessory cells and the Fc portion of an antibody (Steplewski et al., 1983). The binding cross-links FcR to activate the effector cells [e.g., natural killer (NK) cells are triggered to kill cancer cells and also release cytokines and chemokines] (Iannello and Ahmad, 2005). While ADCC can be mediated by NK cells, monocyte-macrophages and neutrophils, NK cells are the principal ADCC effectors as they express low affinity type IIIA Fc receptor (FcR $\gamma$ IIIa; CD16a) on their surface (Ernst et al., 2002; Metes et al., 2001; Morel et al., 1999) and CD16a plays a dominant role in triggering NK cell-mediated ADCC (O'Hanlon, 2004). NK cells kill target cells by directed release of cytotoxic granules containing perforin and granzymes. Antitumor activity of clinically effective mAb against human tumor xenografts growing in either wild-type mice or in murine Fc $\gamma$ RII/III knock out mice (Clynes et al., 2000) was reduced in the Fc $\gamma$ receptor knock-out mice, and was conserved when only the inhibitory Fc $\gamma$ RII receptor isoform was removed, stressing the importance of Fc $\gamma$ RIIIa (CD16a) in anti-tumor responsiveness (Clynes et al., 2000). Antibodies designed to take advantage of Fc functions, such as rituximab, are IgG1 subclass, as opposed to immunoconjugates, designed to kill by drug or toxin delivery, that are usually IgG4 subclass to limit complement activation and toxicity. The role of CD16a in the anti-tumor effects of rituximab is further supported by the finding that patients with $\mathrm{CD} 16$ polymorphisms that generate a high affinity receptor for $\mathrm{Fc}$ correlate with improved outcome of follicular lymphoma responses to rituximab (Weng and Levy, 2003b). Thus interactions between the antibody Fc domain and the Fc receptor underlie at least some of the clinical benefit of some mAb, and imply the importance of ADCC. Ongoing research strategies include molecular manipulation of the $\mathrm{mAb} F \mathrm{c}$ region to enhance complement activation and/or ADCC. Combined computational and experimental methods have identified mutations within the Fc domain of $\mathrm{mAb}$ to selectively tune the affinity for Fc $\gamma$ RIII and other Fc $\gamma$ receptors (Hayes et al., 2002). An alternative strategy to enhance ADCC by mAb is to modify Fc glycosylation by the producing cell line (Umana et al., 1999).

Modification of the Fc region to interact with activating or with inhibitory $\mathrm{Fc}$ receptors also has potential to enhance antigen presentation by dendritic cells and can be biased to promote or to inhibit the generation of cytotoxic T-cell responses against the targeted antigen. In summary, numerous findings indicate that the induction of ADCC can lead to adaptive immune responses and finally to the elimination of tumor cells (Rafiq et al., 2002; Weiner and Carter, 2005).

4.1.2 Antibody binding inducing intracellular signals-Many antibodies targeting cell surface receptors are designed to alter intracellular signaling pathways. Examples include impacts on epidermal growth factor receptor (EGFR) and HER2/neu blockade. Recent data that mutations in intracellular pathways (i.e. K-ras) determine whether antibody binding is cytotoxic indicate an important role for intracellular pathways in antibody anti-tumor activity. 
CD20 is not generally thought of as a signaling molecule, but is known to affect calcium channels (Bubien et al., 1993). Rituximab binding to CD20, particularly when cross-linked, initiates a cascade of intracellular signals, many quite similar to signaling through the B cell receptor (Mathas et al., 2000). When CD20 is bound, it redistributes into cell membrane lipid rafts (Deans et al., 2002; Deans et al., 1998), which appears to be necessary for signal activation. The result of stimulation of these complex signaling pathways (i.e. cell cycle arrest or apoptosis) appears to be cell line specific.

Recent data from patients with chronic lymphocytic leukemia treated with rituximab, supports a role for the induction of apoptosis through the mitochondrial pathway (i.e. activation of caspases 3 and 9, but not caspase 8) and down-regulation of XIAP and mcl-1 (Byrd et al., 2002). Alterations in the set-point for apoptosis, perhaps by changes in levels of bcl-2 or its related family of anti-apoptotic proteins, apoptosome components such as APAF-1, or other regulators of apoptosis sensitivity could lead to antibody resistance and provide mechanisms that could be exploited to enhance activity.

4.1.3 Antibody-induced fixation of complement-Complement activation by the $F_{c}$ portion of an antibody bound to a tumor cell surface can lead to complement-dependent cytotoxicity. Complement activation does take place in patients treated with rituximab, and it appears that the ability of CD20 to move into lipid rafts is required for complement-dependent cytotoxicity to occur (Cragg et al., 2002). Protein fragments indicative of complement activation are measurable in patients. Complement activation has effects other than lysis, including depositing $\mathrm{C} 3, \mathrm{C} 3 \mathrm{~b}$ and $\mathrm{C} 3 \mathrm{~b}$ breakdown products on the cell surface, which are potential targets of $\mathrm{C} 3$-receptors on effector cells, thereby enhancing cell killing by ADCC (see above) (Kennedy et al., 2003). Complement-mediated lysis is regulated by a series of complement inhibitory proteins, including CD35 (complement receptor type, CR1), CD46 (membrane cofactor protein), CD55 (decay accelerating factor) and CD59 (membrane inhibitor of reactive lysis, protectin) (Charles and Foerster). CD55 and CD59 inhibition may enhance antibody-mediated complement-dependent cytotoxicity (Golay et al., 2001; Golay et al., 2000). Fludarabine, clinically used in chronic lymphocytic leukemia and indolent non-Hodgkin lymphoma, down-regulates CD55 and CD59 (Di Gaetano et al., 2001), a potential mechanism of synergy between fludarabine and rituximab.

Subsequent discussion will provide an overview of clinically active antibodies for treating different types of cancer and discuss the available efficacy data for these agents.

\subsection{Antibody therapy of hematologic malignancies}

4.2.1 Rituximab-The chimeric monoclonal antibody rituximab contains a murine derived Fab targeting CD20, a pan-B cell transmembrane protein, and a human Fc segment (Reff et al., 1994). Features making CD20 an attractive target are having high level expression that is not down-regulated by antibody binding and low plasma levels (Grillo-Lopez, 2000).

Rituximab kills normal and malignant $\mathrm{CD} 20^{+}$cells, but fortunately depletion of normal B cells is minimally toxic. The major attributes of Rituximab and other antibodies described in this section are summarized in Table 1.

Single agent rituximab was approved for relapsed/refractory indolent CD20 ${ }^{+}$non-Hodgkin lymphoma based on a response rate in heavily pretreated patients of $48 \%$, with median duration 13 months (McLaughlin et al., 1998). Given the lack of rituximab bone marrow suppression, full doses of chemotherapy and rituximab can be combined and uniformly give better outcomes than chemotherapy alone. Major randomized trials leading to the currently approved indications for rituximab include documented prolonged remissions as initial therapy for indolent non-Hodgkin lymphoma with rituximab-cyclophosphamide-vincristine-prednisone (R-CVP) (Marcus et al., 2005) or rituximab scheduled re-treatment following CVP (Hochster 
et al., 2009),versus CVP alone; and prolonged progression-free and overall survival as initial therapy for aggressive B cell non-Hodgkin lymphoma with rituximab-cyclophosphamidedoxorubicin-vincristine-prednisone (R-CHOP) vs CHOP alone (Coiffier et al., 2002; Habermann et al., 2006; Pfreundschuh et al., 2006; Sehn et al., 2005). Maintenance dosing of rituximab seems to prolong progression-free survival in indolent non-Hodgkin lymphoma, though dose and schedule have been variable and effects on survival require longer follow-up.

Each of the three main proposed mechanisms for rituximab-mediated cytotoxicity might be manipulated to enhance cytotoxicity. Cell signaling after rituximab is complex and under active investigation (Bonavida, 2007), but could be altered by signal pathway inhibitors. Any clinical effects, however, remain empiric. Complement activity may be enhanced by down-regulating complement inhibitory proteins (Manches et al., 2002) such as CD55 and CD59, which is an effect of fludarabine, raising this as a possible synergistic interaction (Di Gaetano et al., 2001). ADCC effects reflect $F c$ receptor binding affinities as CD16a polymorphisms alter rituximab single agent effects (Cartron et al., 2002; Weng and Levy, 2003a), however, R-chemo seems to overcome this effect (Carlotti and Pulsoni, 2007). Strategies to enhance ADCC, such as blocking inhibitory signals to killer cells, are under investigation (Binyamin et al., 2008).

Combination of active agents that also are immune modulating, such as lenalidomide and thalidomide, with rituximab may be additive (Kaufmann, 2004), and perhaps synergize by increasing ADCC (Reddy, 2008). The ability to restore the effector cell compartments with cytokines such as interleukin-2, -12 or -15 and myeloid growth factors, or potentially with cellular replacement therapy, may also enhance therapeutic antibody activity, as suggested by pre-clinical data demonstrating that IL-2 can promote NK cell development and enhance rituximab activity (Hooijberg et al., 1995) and clinical trials (Friedberg et al., 2002) (Khan, 2006). Myeloid growth factors in combination with rituximab may also activate ADCC (van der Kolk, 2003). Alternative approaches to induce effector cell activity by combining TLR agonists, such as CpG oligonucleotides, are also being investigated (Warren et al., 2000).

Since most pathways of cytotoxicity ultimately require apoptosis, altering the balance of proand anti-apoptotic signals could generate more cytotoxicity. As anti-apoptotic bcl2 is important in promoting survival of chronic lymphocytic leukemia and non-Hodgkin lymphoma tumors, bcl-2 down-regulation by antisense oligonucleotides was found to enhance rituximab efficacy in pre-clinical testing (Ramanarayanan et al., 2004; Smith et al., 2004). Clinical trials of the bcl-2 antisense, oblimersen, in combination with rituximab have been promising, however, small molecules that bind to the BH-3 domain common to many members of the bcl-2 family of proteins may be better therapeutic agents (Nguyen, 2007; Paoluzzi, 2008; van Delft, 2006).

4.2.2 Additional anti-CD20 antibodies under development-Rituximab can cause infusion related reactions, development of human anti-mouse antibodies and eventually clinical rituximab resistance does develop. The humanized anti-CD20 antibodies veltuzumab (Stein, 2004), ocrelizumab and ofatumumab (Coiffier et al., 2008) may decrease human anti-mouse antibody development and reduce infusion-related reactions. Ofatumumab also binds a different CD20 epitope and is engineered for better complement activation, although it induces less ADCC. Other engineered antibodies enhance ADCC, but activate less complementdependent cytotoxicity (Bowles, 2006).

4.2.3 Additional antibodies to treat non-Hodgkin lymphoma-CD22 is a pan B cell marker internalized upon antibody binding. Epratuzumab is a humanized anti-CD22 that exhibits modest activity alone and combined with rituximab (Leonard JP et al., 2004) (Leonard JP and T, 2005) (Strauss, 2006). Radiolabeled epratuzumab is also being studied (Lindén and Ohlsson, 2005). Building on the success of an anti-CD33-chalicheamycin drug conjugate in treating myeloid leukemia, and since CD22 is internalized upon antibody binding, the anti- 
CD22-chalicheamycin drug conjugate inotuzumab ozogomicin, is well tolerated and active in relapsed/refractory B cell non-Hodgkin lymphoma as a single agent (Fayad, 2006) and combined with rituximab. CD22-pseudomonas immunotoxins are also active in treating the indolent B cell malignancy hairy cell leukemia. (Kreitman, 2001) The pan-B cell antigen CD19, for reasons that remain elusive, has not proven to be as effective a target as CD20 (Stone, 1996) (Grossbard, 1999). Further research targeting CD19 is ongoing. CD74, an MHC class II chaperone (Stein, 2007) with survival signaling effects (Starlets, 2006; Stein et al., 2009) is expressed on most B cell malignancies including myeloma, and is targeted by the humanized anti-CD74 antibody milatuzumab.

Humanized alemtuzumab recognizes CD52, which is expressed on B, T and NK cells, monocytes and macrophages, and has been found to be quite immunosuppressive. Approved for chronic lymphocytic leukemia therapy (Demko, 2008), it is also active in T cell diseases such as T-prolymphocytic leukemia (Keating and Maughan, 2002) and cutaneous T cell lymphoma.

4.2.4 Antibodies targeting lymphocyte activation markers-CD23 is expressed on B-chronic lymphocytic leukemia cells, as well as a normal subset of B cells. The chimeric macaque-human anti-CD23 antibody lumiliximab is active against chronic lymphocytic leukemia (Byrd and Wynne, 2007) and has been combined with standard chemotherapy in recent studies (Byrd, 2006). CD25, a component of the high affinity IL-2 receptor expressed on a variety of B and T cell lymphomas, has been targeted by a single chain anti-CD25 Fv fragment-pseudomonas exotoxin conjugate, which is active against $\mathrm{CD} 25^{+}$lymphomas (Kreitman and Waldmann TA, 2000). An IL-2-diptheria toxin conjugate, which also targets $\mathrm{CD} 25$, is already approved for use in chronic $\mathrm{T}$ cell leukemia and is active against other B (Dang, 2004) and T (Dang, 2007) cell lymphomas. CD80, a B7 ligand receptor family transmembrane glycoprotein, is normally involved in $\mathrm{T}$ cell co-stimulatory pathways. It is constitutively expressed on many malignant B cells, Hodgkin lymphoma Reed-Sternberg cells, and transiently on activated B cells and antigen presenting cells. The primatized anti-CD80 antibody, galiximab, may function via typical anti-tumor mechanisms, but also by blocking stimulatory CD28-CD80 interactions, potentially affecting activation of Treg cells and cytokine production to influence the tumor microenvironment (Czuczman, 2005) (Leonard, 2007).

4.2.5 Antibodies targeting TNF-related pathways-CD30 is present on anaplastic large cell lymphoma and Hodgkin lymphoma Reed-Sternberg cells. Antibody binding to CD30 may signal apoptosis, inhibit proliferation or induce complement-dependent cytotoxicity or ADCC. Murine, chimeric and humanized anti-CD30 antibodies (Bartlett and Bernstein, 2008) (Ansell SM and Blanset D, 2007) are well tolerated with limited activity in treating anaplastic large cell lymphoma and Hodgkin lymphoma. Engineered forms of these antibodies having enhanced Fc-receptor binding or as immunoconjugates are in clinical trials. CD40 is important in normal B cell development and expressed on various B cell malignancies, including myeloma and Hodgkin lymphoma Reed-Sternberg cells. The CD40 ligand CD154 is present on activated $\mathrm{T}$ cells, and interaction with CD40 on B and dendritic cells activates antigen presentation. Thus, CD40 binding by antibodies may result in a variety of anti-tumor effects, including immune stimulation. CD40 ligand and anti-CD40 antibodies with agonistic or antagonistic effects are also being studied (Vonderheide and Sullivan, 2007) (Advani, 2006). The TNF family of receptors can activate killing, as seen with CD30 and CD40. TNF-related apoptosis inducing ligand (TRAIL) induces apoptosis through the TRAIL receptors DR4 (TRAIL-R1) and DR5 (TRAIL-R2) on tumor cells (Griffith, 1999). Recombinant forms of TRAIL, as well as agonistic anti-receptor antibodies, induce apoptosis of tumors and are currently in clinical trials (Younes, 2005). 
4.2.6 Immunomodulatory antibodies-Along with accumulating evidence that patients with cancer may mount an immune response to their tumors (Hudson et al., 2007; Jager, 2007; Wang et al., 2005), tumors also create an immune suppressive environment locally and systemically that could inhibit such an immune response. Many mechanisms have been proposed for these inhibitory effects. Modulation of co-stimulatory and co-inhibitory molecules is thought to contribute to these immune subversion mechanisms. Examples include molecules and families of proteins such as B7-H1 (programmed death ligand-1) that interacts with the co-inhibitory programmed death receptor-1 (PD-1, CD279) on T cells (Blank et al., 2005) and cytotoxic T lymphocyte antigen-4 (CTLA-4) (Korman et al., 2006). A number of recently introduced candidate antibodies for cancer therapy specifically target these inhibitory receptors or their ligands (Korman et al., 2005; Sanderson et al., 2005).

Initiation of a tumor specific immune response requires the presentation of tumor antigen to $\mathrm{T}$ cells by an antigen presenting cell in the context of MHC molecules. T cell activation requires two events: recognition of antigen/MHC complex by T cell receptor and a co-stimulatory signal delivered through CD80 and CD86 on the antigen presenting cell surface interacting with CD28 on the $\mathrm{T}$ cell. This process results in T-cell activation and proliferation (Fong and Small, 2008; Korman et al., 2006). Following activation, CTLA-4, is expressed on the surface of T cells, binds CD80 and 86 , and provides inhibitory signals to the $\mathrm{T}$ cell as part of a negative feedback loop (Fong and Small, 2008). The negative regulation of the immune response maintains peripheral tolerance to self-antigens and prevents damage to normal host tissue (Korman et al., 2006). Theoretically, blocking CTLA-4 with mAbs may sustain the activation and proliferation of tumor specific T cells, promoting the development of an effective tumorspecific immune response (Fong and Small, 2008).

The exact mechanism of action of anti-CTLA- 4 antibodies has not been determined. Kavanagh and colleagues recently showed that treatment with the CTLA-4 antibody, ipilimumab, can expand functional Treg cells in humans (Kavanagh et al., 2008). Alternatively, CTLA-4 blockade could act directly on effector $\mathrm{CD}^{+}$and/or $\mathrm{CD} 8^{+} \mathrm{T}$ cells by removing a checkpoint on their proliferation and function (Fong and Small, 2008).

A co-stimulatory molecule, CD137 (4-1BB), has also been studied for its potential role in immune modulation. This molecule belongs to the TNF receptor family and is expressed on multiple immune cell subsets, particularly following their activation. Ligation of CD137 using agonist anti-CD137 monoclonal antibodies (mAbs) leads to co-stimulation of T and NK cells and eradication of established tumors in multiple murine models (Melero et al., 1997; Miller et al., 2002; Nam et al., 2005; Wilcox et al., 2002). Clinical studies of BMS-663513, an IgG4 anti-human CD137 mAb, are ongoing in patients with solid tumors, with objective responses seen, primarily in melanoma (Sznol M., 2008).

PD-1 is a member of the CD28 superfamily and plays an important role as an inhibitor of $\mathrm{T}$ cell responses (Greenwald et al., 2005). A higher content of PD- $1^{+}$cells predicted improved survival in patients with follicular lymphoma (Carreras et al., 2009), while patients with higher grade follicular lymphoma and poor prognostic features had a lower level of PD- $1^{+}$cells. Blank and colleagues reported that the interaction between PD-1 and its ligand, PD-L1, negatively regulated T cell effector functions (Blank et al., 2006). These investigators showed that PDL1 was constitutively expressed on human renal cell carcinoma (RCC) cell lines and upregulated on human melanoma cell lines upon exposure to IFN- $\gamma$. PD-L1 expression was found on frozen sections from RCC and melanomas, but not on normal tissues. This supports the notion that PD-L1 is a mediator of tumor escape from tumor-specific T cells (Blank et al., 2006). 
Additional trials are ongoing with these and other immunomodulatory antibodies. A better understanding of the mechanism of action of these molecules along with better knowledge regarding their potential side effects is needed before they can achieve widespread use in the clinic, however.

\subsection{Antibody therapy of solid tumors}

4.3.1 Trastuzumab-Trastuzumab (Herceptin $\left.{ }^{\circledR}\right)$ HER-2/neu (c-erbB-2), a member of the epidermal growth factor receptor (EGFR) family, has been targeted for antibody therapy because it is overexpressed on $25 \%$ of breast cancers, as well as other adenocarcinomas of the ovary, prostate, lung, and gastrointestinal tract. Trastuzumab (Baselga et al., 1996; Cobleigh et al., 1999), a humanized antibody derived from the murine mAb 4D5, recognizes an epitope on the extracellular domain of HER-2/neu. Over-expression of HER-2/neu that is associated with gene amplification correlates with a clinical response to trastuzumab. Earlier studies utilized variable criteria to define HER2 expression, which may account for the differences in the response rates observed in these studies (von Mehren et al., 2003). The major attributes of Trastuzumab and other antibodies described in this section are summarized in Table 2.

Early studies with this agent established its role in patients with metastatic disease. A phase II study of trastuzumab, in women with metastatic breast cancer who were treated with $2 \mathrm{mg} / \mathrm{kg}$ weekly, showed an objective response rate of $16 \%$ (Cobleigh et al., 1999). Improvement in the median response rate and overall survival were noted.

A large, randomized phase III trial evaluating cytotoxic chemotherapy alone or with weekly trastuzumab has shown the efficacy of combination therapy (Slamon et al., 2001). Patients receiving initial therapy for metastatic breast cancer were treated with cyclophosphamide plus an anthracycline, or with paclitaxel if they had received an anthracycline in the adjuvant setting. Response rates for combination therapy were higher regardless of the chemotherapy used. Furthermore, addition of trastuzumab to chemotherapy improved survival at one year by $16 \%$ (Norton et al., 1999) and improved survival at 29 months by 25\% (Baselga, 2001a). Myocardial dysfunction was observed more frequently in patients receiving doxorubicin or epirubicin when trastuzumab was added. Therefore, trastuzumab is not recommended in combination with anthracyclines. Based on these clinical trial results, trastuzumab was approved by the FDA to treat women with metastatic breast cancer with HER-2/neu overexpression, either alone or in combination with paclitaxel. Trastuzumab also has activity in combination with other chemotherapeutic agents (Burstein et al., 2001; Pegram et al., 1998). In addition two randomized trials have shown that trastuzumab in the adjuvant setting can lead to a $33 \%$ reduction in the risk of death (Romond et al., 2005).

Trastuzumab is a success story in breast cancer therapy. However, despite the overexpression of Her2/neu in other solid tumors, such as non-small cell lung cancer, to date no significant clinical benefit of trastuzumab has been seen in patients with diseases other than breast cancer.

4.3.2 Epidermal Growth Factor Receptor (EGFR) Antibodies-EGFR is a widely expressed glycoprotein with three main domains: The extracellular ligand binding domain can bind to a number of regulatory factors, such as EGF and transforming growth factor- $\alpha$ (TGF$\alpha$ ), leading to EGFR dimerization and autophosphorylation. The hydrophobic transmembrane portion connects the extra- and intracellular portions. The cytoplasmic domain responds to receptor autophosphorylation by increasing the tyrosine kinase catalytic activity (Lockhart and Berlin, 2005). This, in turn, leads to phosphorylation of other tyrosine motifs and activation of a number of intracellular signaling pathways such as phosphatidylinositol-3 kinase (PI3K) and Akt, which result in cellular proliferation, differentiation, transformation and anti-apoptotic functions. 
The possible role of EGFR overexpression in tumor growth and development has been best studied in colorectal cancers (Lockhart and Berlin, 2005). It is generally accepted that EGFR overexpression is found in 65\% to $70 \%$ of colorectal carcinomas (Messa et al., 1998), even though there is heterogeneity in tumor biopsies and lack of a uniform method of evaluating levels of EGFR. The available anti-EGFR monoclonal antibodies bind to the receptor and block the binding of the ligand to prevent downstream events. Cetuximab (C225) is a chimeric monoclonal antibody directed against the extracellular domain of the EGFR. Panitumomab (ABX-EGF) is a fully human IgG2 monoclonal antibody against EGFR generated through the Xenomouse transgenic strain in which human immunoglobulin genes replace mouse immunoglobulin genes (Lockhart and Berlin, 2005). Both of these antibodies are capable of inhibiting the growth of EGFR expressing cell lines in vitro and in vivo (Baselga, 2001b; Yang et al., 2001). Cetuximab is capable of enhancing the anti-tumor effects of chemotherapy and radiation therapy in preclinical and clinical studies. Proposed mechanisms by which anti-EGFR mAbs can elicit an anti-tumor response include receptor internalization and subsequent degradation, interference with EGFR signaling by preventing ligand binding and induction of ADCC. Another proposed mechanism that is less well understood invokes interference with signaling events via antibody disruption of lipid rafts. The EGFR is intimately associated with signaling microplatforms on the cellular membrane (Puri et al., 2005). High concentration of EGFR ligands or, perhaps, cross-linking with an antibody may shuttle EGFR internalization from the clathrin-mediated pathway of recycling to the caveolin-associated route leading to receptor ubiquitination and degradation (Sigismund et al., 2005).

Cetuximab has been used either alone or in combination with radiotherapy or various chemotherapeutic agents primarily in patients with head and neck or colorectal cancers. The most common side effects seen with this agent are an acneiform rash and occasional allergic reactions. A number of earlier trials showed efficacy of cetuximab as a single agent or in combination with chemotherapy. Although single agent cetuximab activity in colorectal cancer is low, a response rate of $22.5 \%$ was achieved in combination with irinotecan (Saltz L et al., 2001; Saltz et al., 2004). A subsequent randomized phase III trial involving 329 patients with $\mathrm{EGFR}^{+}$, irinotecan-refractory colorectal cancers showed a significantly higher response rate (22.9 versus $10.8 \%$ ) and median time to progression in the combination arm (Cunningham et al., 2004). Cetuximab has been approved by the FDA for the treatment of advanced or refractory colorectal cancers, in conjunction with irinotecan.

The first randomized clinical trial to demonstrate a statistically-significant survival benefit by use of any EGFR antagonist is in squamous cell carcinoma of the head and neck. In the pivotal multi-center trial in head and neck squamous cell carcinoma (Bonner et al., 2006), 424 patients underwent randomization to definitive radiotherapy alone or in combination with weekly cetuximab. Bonner et al. reported doubling of median duration of locoregional control from 14.9 to 24.4 months (log-rank $\mathrm{P}=0.005$ ). The 3 -year survival rates were $54 \%$ versus $45 \%$ in favor of cetuximab and radiotherapy. Locoregional control and survival benefits persist (Robert et al., 2001). Of interest, there was no influence of EGFR expression on patient outcome.

In advanced stage non-small cell lung cancer expressing EGFR, the combination of cetuximab and standard doublet chemotherapy has been studied in a prospective randomized phase III trial (Pirker et al., 2009). Addition of cetuximab was associated with a slight, but statistically significant, benefit in overall survival over chemotherapy alone (median overall survival 10.1 vs. 11.3 mos, $\mathrm{P}=0.0441$ ).

4.3.3 Vascular endothelial growth factor (VEGF) antibodies-Pioneering work of Folkman and others (O'Reilly et al., 1994) showed that malignant tumor progression requires new blood vessels capable of delivering essential nutrients and oxygen and blockade or damage of tumor vessels deprives malignant cells of essential nutrients and causes tumor destruction. 
Since one vessel supplies a vast number of cancer cells, this approach can amplify the consequences of an initial cytotoxic insult. Moreover, this strategy does not require the penetration of other cells or molecules into the tumor parenchyma.

Of the identified angiogenic factors, VEGF is the most potent and specific regulator of both normal and pathologic angiogenesis (Ferrara and Davis-Smyth, 1997). VEGF produces a number of biologic effects, including endothelial cell mitogenesis and migration, induction of proteinases leading to remodeling of the extracellular matrix, increased vascular permeability, and maintenance of survival for newly formed blood vessels (Ferrara and Davis-Smyth, 1997). The biologic effects of VEGF are mediated through binding and stimulation of two receptors on the surface of endothelial cells: Flt-1 (fms-like tyrosine kinase, VEGFR1) and KDR (kinase domain region, VEGFR2) (Davis-Smyth et al., 1996; Ferrara and Davis-Smyth, 1997).

Increased expression of VEGF has been demonstrated in most human tumors examined to date, including tumors of the lung, breast, thyroid, gastrointestinal tract, kidney, bladder, ovary, and cervix, as well as angiosarcomas and glioblastomas (Ferrara and Davis-Smyth, 1997).

Inhibition of VEGF by using an anti-VEGF monoclonal antibody blocks the growth of a number of human cancer cell lines in nude mice (Ferrara and Davis-Smyth, 1997). In addition, the combination of anti-VEGF antibody and chemotherapy in nude mice injected with human cancer xenografts results in an increased antitumor effect compared with antibody or chemotherapy treatment alone (Borgstrom et al., 1999).

Bevacizumab is a recombinant humanized monoclonal antibody targeting VEGF (Presta et al., 1997). Clinical trials including patients with a variety of tumor types: colorectal, breast, lung, and renal carcinoma have established the role of this monoclonal antibody in the treatment of metastatic cancer (D'Adamo et al., 2005; Hurwitz et al., 2004b; Hurwitz et al., 2005; Miller et al., 2005b). In a randomized phase III study in patients with metastatic colorectal cancer, Hurwitz and colleagues assigned 815 patients to receive either irinotecan, 5-flourouracil and leucovorin (IFL) with bevacizumab or IFL with placebo (Hurwitz et al., 2004a). The addition of bevacizumab led to a statistically significant increase in the response rate and a 4.7-month prolongation in median overall survival (to 20.3 months, vs. 15.6 months with IFL and placebo). In this study, bevacizumab was associated with reversible hypertension and proteinuria and was relatively well tolerated.

A randomized phase III trial (ECOG 4599) of paclitaxel and carboplatin with or without bevacizumab in patients with advanced non-squamous non-small cell lung cancer led to a significant improvement in median survival (12.5 months vs. 10.2 months; $\mathrm{P}=.0075$ ) for patients in the bevacizumab arm. In addition, patients treated with bevacizumab had a significantly higher response rate $(27 \%$ vs. $10 \%$; $\mathrm{P}<.0001)$ and a significantly longer progression-free survival time $(6.4$ months vs. 4.5 months; $\mathrm{P}<.0001)$. A higher incidence of bleeding was associated with bevacizumab $(4.5 \%$ vs. $0.7 \%)$. Five of ten treatment-related deaths occurred as a result of hemoptysis, all in the bevacizumab arm.

A phase III trial randomized 722 patients with metastatic breast cancer with no prior chemotherapy for advanced disease to either paclitaxel or paclitaxel and bevacizumab (Miller et al., 2007b). Progression free survival was significantly better in the paclitaxel plus bevacizumab arm (median, 11.8 vs. 5.9 months; hazard ratio for progression, $0.60 ; \mathrm{P}<0.001$ ) with an increased response rate ( $36.9 \%$ vs. $21.2 \%, \mathrm{P}<0.001)$. Overall survival, however, was similar in the two groups (median, 26.7 vs. 25.2 months; hazard ratio, $0.88 ; \mathrm{P}=0.16$ ).

Miller and colleagues (Miller et al., 2005c) reported the results of a randomized phase III trial of capecitabine/bevacizumab versus capecitabine alone in 462 anthracycline and taxane pretreated metastatic breast cancer patients. The primary end point of this study, progression- 
free survival, did not show a statistically significant difference (4.86 vs. 4.17 months; hazard ratio $=0.98)$. Combination therapy significantly increased the response rates $(19.8 \%$ vs. $9.1 \%$; $\mathrm{P}=.001)$. Overall survival (15.1 vs. 14.5 months) and time to deterioration in quality of life were comparable in both treatment groups.

Five major bevacizumab-associated toxicities have been identified: hypertension, proteinuria, thromboembolic events, hemorrhage and congestive heart failure. The rates of clinically meaningful events have been low, however, and because of these potential adverse events, a number of patients with advanced disease are not eligible for treatment with this agent.

\subsection{Radioimmunotherapy}

Unlabeled antibody may not have access to all tumor cells nor kill all targeted cells. Many factors affect cell killing, including surface antigen density, antibody penetration into lymph nodes or tumors, and local accessibility to complement and cytotoxic cells. Using antibodydrug conjugates may overcome low antigen density and lack of necessary local immune cells. Several of these are discussed above. Alternatively, radioactively-tagged antibodies can target adjacent cells and may not require immune functions. The two approved radioimmunotherapy agents, $\mathrm{Y}^{90}$-ibritumomab tiuxetan and ${ }^{131}$ I-tositumomab appear to have similar efficacy (Davies, 2007; Jacene, 2007). Response rates are high with toxicity mainly delayed by myelosuppression, (Fisher, 2005).(Horning, 2005) (Kaminski, 2005; Witzig et al., 2002). Radioimmunotherapy has been used to consolidate remissions after chemotherapy with promising results (Press, 2007) (Leonard, 2005) (Smith, 2007). Another research area utilizes radioimmunotherapy prior to stem cell transplant (Gopal, 2007; Krishnan, 2008).

Radioimmunotherapy utility may be improved by re-treatment, radiosensitizing agents and pre-targeting (Goldenberg, 2008). Radioimmunotherapy responses in rituximab-refractory patients suggests a different mechanism of action, i.e. targeted radiation therapy, rather than antibody-dependent killing. Radioimmunotherapy resistance may therefore indicate an intrinsic altered apoptotic threshold of the lymphoma cell, raising the possibility of overcoming this as another potential therapeutic strategy.

\section{Concluding remarks}

While targeted immune therapies offer new possibilities to harness the immune response to treat cancer patients, effective manipulation of the immune system may require overcoming barriers, while avoiding potential hazardous complications. Barriers include elimination of the tumor-specific antigen or overcoming immune tolerance within the tumor microenvironment, which can be due to the production of immunosuppressive cytokines (such as IL-10, TGF- $\beta$, and type 2 cytokines) or the presence of immuosuppressive cells (such as tumor-associated macrophages, myeloid-derived suppressor cells, and Treg cells). Although not detailed here, many immune-potentiating therapies designed to target these immunosuppressive molecules and cells are also under development. On the other hand, the removal of normal tolerance mechanisms can also trigger autoimmune responses or graft-versus-host disease, which can cause significant and even life-threatening complications. Immune tolerance mechanisms play important roles in maintaining homeostasis and preventing autoimmunity, and altering these mechanisms can have unexpected negative repercussions in patients. Furthermore, it must be recognized that therapies designed to establish adaptive immune responses toward a tumor mass may not effectively target the minor subpopulation of cancer stem cells that support tumor development and recurrence, since those progenitor cells may express distinct antigens. Therefore, future targeted immunotherapies may be necessary that specifically direct immune reactivity toward these cancer stem cells.

One must also consider that many of the radiation and chemotherapeutic agents used to treat cancer can significantly suppress normal immune function. Therefore, immunotherapies must 
precede treatment with immunosuppressive anti-cancer agents, since it may be impossible to potentiate a compromised immune system. On the other hand, tumor-targeted radiation treatments do not result in generalized immunosuppression, and may actually enhance antitumor immune responses by releasing antigens from dying tumor cells for uptake and presentation by antigen presenting cells (Ferrara et al., 2009). Immunotherapy will likely not be able to eliminate tumors alone, but combination therapies that incorporate immunotherapeutic agents have great potential for providing clinical success in treating cancer in the coming years.

\section{Acknowledgments}

The authors thank Isabelle Cruz for assistance in preparation of the manuscript. This work was supported by grants CA083859, CA100226 (K.S.C.) and Centers of Research Excellence grant CA06927 from the National Cancer Institute (NCI) of the National Institutes of Health, an appropriation from the Commonwealth of Pennsylvania, and support from the Blood Cell Development and Cancer Keystone Program at Fox Chase Cancer Center. The contents are solely the responsibility of the authors and do not necessarily represent the official views of the NCI.

\section{References}

Advani R, Forero-Torres A, Furman RR, et al. SGN-40(Anti-huCD40 mAb) monotherapy induces durable objective responses in patients with relapsed aggressive non-Hodgkin's lymphoma:evidence of anti-tumor activity from a Phase I study. Blood 2006;108:A695.

Ahmad A, Menezes J. Antibody-dependent cellular cytotoxicity in HIV infections. Faseb J 1996;10:258266. [PubMed: 8641559]

Allan SE, Broady R, Gregori S, Himmel ME, Locke N, Roncarolo MG, Bacchetta R, Levings MK. CD4 + T-regulatory cells: toward therapy for human diseases. Immunol. Rev 2008;223:391-421. [PubMed: 18613849]

Anfossi N, Andre P, Guia S, Falk CS, Roetynck S, Stewart CA, Breso V, Frassati C, Reviron D, Middleton D, Romagne F, Ugolini S, Vivier E. Human NK cell education by inhibitory receptors for MHC class I. Immunity 2006;25:331-342. [PubMed: 16901727]

Ansell SM, Horwitz SM, Engert A, Khan KD, Lin T, Strair R, Keler T, Graziano R, Blanset D, Yellin M, Fischkoff S, Assad A, Borchmann P. Phase I/II study of an anti-CD30 monoclonal antibody (MDX-060) in Hodgkin's lymphoma and anaplastic large-cell lymphoma. J. Clin. Oncol 2007;25:2764-2769. [PubMed: 17515574]

Bartlett N, Younes A, Carabasi MH, Forero A, Rosenblatt JD, Leonard JP, Bernstein S, Bociek RG, Lorenz JM, Hart BW, Barton J. A phase 1 multidose study of SGN-30 immunotherapy in patients with refractory or recurrent CD30+ hematologic malignancies. Blood 2008;111:1848-1854. [PubMed: 18079362]

Baselga J. Clinical Trials of Herceptin ${ }^{R}$ (trastuzumab). European Journal of Cancer 2001;37:S18-S24. [PubMed: 11167087]

Baselga J. The EGFR as a target for anticancer therapy--focus on cetuximab. Eur J Cancer 37 Suppl 2001;4:S16-22.

Baselga J, Tripathy D, Mendelsohn J, Baughman S, Benz C, Dantis L, Sklarin N, Seidman A, Hudis C, Moore J, Rosen P, Twaddell T, Henderson I, Norton L. Phase II study of weekly intravenous recombinant humanized anti-p185HER2 monoclonal antibody in patients with HER2/neuoverexpressing metastatic breast cancer. J. Clin. Oncol 1996;14:737-744. [PubMed: 8622019]

Becker Y. Molecular immunological approaches to biotherapy of human cancers--a review, hypothesis and implications. Anticancer Res 2006;26:1113-1134. [PubMed: 16619514]

Beelen DW, Ottinger HD, Ferencik S, Elmaagacli AH, Peceny R, Trenschel R, Grosse-Wilde H. Genotypic inhibitory killer immunoglobulin-like receptor ligand incompatibility enhances the longterm antileukemic effect of unmodified allogeneic hematopoietic stem cell transplantation in patients with myeloid leukemias. Blood 2005;105:2594-2600. [PubMed: 15536148]

Benhar I, Azriel R, Nahary L, Shaky S, Berdichevsky Y, Tamarkin A, Wels W. Highly efficient selection of phage antibodies mediated by display of antigen as Lpp-OmpA' fusions on live bacteria. J. Mol. Biol 2000;301:893-904. [PubMed: 10966794] 
Binyamin L, Alpaugh RK, Hughes TL, Lutz CT, Campbell KS, Weiner LM. Blocking NK cell inhibitory self-recognition promotes antibody-dependent cellular cytotoxicity in a model of anti-lymphoma therapy. J. Immunol 2008;180:6392-6401. [PubMed: 18424763]

Blank C, Gajewski TF, Mackensen A. Interaction of PD-L1 on tumor cells with PD-1 on tumor-specific T cells as a mechanism of immune evasion: implications for tumor immunotherapy. Cancer Immunol. Immunother 2005;54:307-314. [PubMed: 15599732]

Blank C, Kuball J, Voelkl S, Wiendl H, Becker B, Walter B, Majdic O, Gajewski TF, Theobald M, Andreesen R, Mackensen A. Blockade of PD-L1 (B7-H1) augments human tumor-specific T cell responses in vitro. Int. J. Cancer 2006;119:317-327. [PubMed: 16482562]

Blumberg BS. Hepatitis B virus, the vaccine, and the control of primary cancer of the liver. Proc. Natl. Acad. Sci. U.S.A 1997;94:7121-7125. [PubMed: 9207053]

Bonavida B. Rituximab-induced inhibition of antiapoptotic cell survival pathways: implications in chemo/immunoresistance, rituximab unresponsiveness, prognostic and novel therapeutic interventions. Oncogene 2007;26:3629-3636. [PubMed: 17530016]

Bonner JA, Harari PM, Giralt J, Azarnia N, Shin DM, Cohen RB, Jones CU, Sur R, Raben D, Jassem J, Ove R, Kies MS, Baselga J, Youssoufian H, Amellal N, Rowinsky EK, Ang KK. Radiotherapy plus Cetuximab for Squamous-Cell Carcinoma of the Head and Neck. N. Engl. J. Med 2006;354:567578. [PubMed: 16467544]

Borgstrom P, Gold DP, Hillan KJ, Ferrara N. Importance of VEGF for breast cancer angiogenesis in vivo: implications from intravital microscopy of combination treatments with an anti-VEGF neutralizing monoclonal antibody and doxorubicin. Anticancer Res 1999;19:4203-4214. [PubMed: 10628376]

Born WK, Jin N, Aydintug MK, Wands JM, French JD, Roark CL, O'Brien RL. gammadelta T lymphocytes-selectable cells within the innate system? J. Clin. Immunol 2007;27:133-144. [PubMed: 17333410]

Bowles J, Wang SY, Link BK, Allan B, Beuerlein G, Campbell MA, Marquis D, Ondek B, Wooldridge JE, Smith BJ, Breitmeyer JB, Weiner GJ. Anti-CD20 monoclonal antibody with enhanced affinity for CD16 activates NK cells at lower concentrations and more effectively than rituximab. Blood 2006;108:2648-2654. [PubMed: 16825493]

Brekke OH, Sandlie I. Therapeutic antibodies for human diseases at the dawn of the twenty-first century. Nat. Rev. Drug Discov 2003;2:52-62. [PubMed: 12509759]

Brunstein CG, Wagner JE, Weisdorf DJ, Cooley S, Noreen H, Barker JN, Defor T, Verneris MR, Blazar BR, Miller JS. Negative effect of KIR alloreactivity in recipients of umbilical cord blood transplantation depends on transplantation conditioning intensity. Blood 2009;113:5628-5634. [PubMed: 19329778]

Bubien JK, Zhou LJ, Bell PD, Frizzell RA, Tedder TF. Transfection of the CD20 cell surface molecule into ectopic cell types generates a $\mathrm{Ca}^{+2}$ conductance found constitutively in B lymphocytes. J. Cell Biol 1993;121:1121-1132. [PubMed: 7684739]

Burstein HJ, Kuter I, Campos SM, Gelman RS, Tribou L, Parker LM, Manola J, Younger J, Matulonis U, Bunnell CA, Partridge AH, Richardson PG, Clarke K, Shulman LN, Winer EP. Clinical activity of trastuzumab and vinorelbine in women with HER2-overexpressing metastatic breast cancer. J. Clin. Oncol 2001;19:2722-2730. [PubMed: 11352965]

Byrd J, Castro J, O'Brien S, Flinn IW, Forero-Torres A, Kipps TJ, Heerema NA, Lin T, Kheoh T, Wynnern D, Molina A. Comparison of results from a Phase 1/2 study of lumiliximab (anti-CD23) in combination with FCR for patients with relapsed CLL with published FCR results. Blood 2006;108:32.

Byrd J, O'Brien S, Flinn IW, Kipps TJ, Weiss M, Rai K, Lin TS, Woodworth J, Wynne D, Reid J, Molina A, Leigh B, Harris S. Phase 1 study of lumiliximab with detailed pharmacokinetic and pharmacodynamic measurements in patients with relapsed or refractory chronic lymphocytic leukemia. Clin. Cancer Res 2007;13:4448-4455. [PubMed: 17671129]

Byrd JC, Kitada S, Flinn IW, Aron JL, Pearson M, Lucas D, Reed JC. The mechanism of tumor cell clearance by rituximab in vivo in patients with B-cell chronic lymphocytic leukemia: evidence of caspase activation and apoptosis induction. Blood 2002;99:1038-1043. [PubMed: 11807010] 
Carlotti E, Palumbo GA, Oldani E, Tibullo D, Salmoiraghi S, Rossi A, Golay J, Pulsoni A, Foà R, Rambaldi A. FcgammaRIIIA and FcgammaRIIA polymorphisms do not predict clinical outcome of follicular non-Hodgkin's lymphoma patients treated with sequential CHOP and rituximab. Haematologica 2007;92:1127-1130. [PubMed: 17650444]

Carreras J, Lopez-Guillermo A, Roncador G, Villamor N, Colomo L, Martinez A, Hamoudi R, Howat WJ, Montserrat E, Campo E. High Numbers of Tumor-Infiltrating Programmed Cell Death 1-Positive Regulatory Lymphocytes Are Associated With Improved Overall Survival in Follicular Lymphoma. J. Clin. Oncol 2009;27:1470-1476. [PubMed: 19224853]

Cartron G, Dacheux L, Salles G, Solal-Cellgny P, Bardos P. Therapeutic activity of humanized anti-CD20 monoclonal antibody and polymorphism in IgG Fc receptor Fc $\gamma$ RIIIa gene. Blood 2002;99:754-758. [PubMed: 11806974]

Charles, J.; Foerster, P.a.J. Mechanisms of immune destruction of erythrocytes.. In: Richard Lee, G.; John, F.; Lukens, John; Paraskevas, Frixos; Greer, John; Rodgers, George M., editors. Wintrobe's Clinical Hematology. Williams \& Wilkins; p. 1191M.D.M.D.M.D.M.D.M.D.M.D., Ph.D.

Clynes RA, Towers TL, Presta LG, Ravetch JV. Inhibitory Fc receptors modulate in vivo cytoxicity against tumor targets. Nat. Med 2000;6:443-446. [PubMed: 10742152]

Cobleigh M, Vogel C, Tripathy D, Robert N, Scholl S, Fehrenbacher L, Wolter J, Paton V, Shak S, Lieberman G, Slamon D. Multinational study of the efficacy and safety of humanized anti-HER2 monoclonal antibody in women who have HER2-overexpressing metastatic breast cancer that has progressed after chemotherapy for metastatic disease. J. Clin. Oncol 1999;17:2639-2648. [PubMed: 10561337]

Coiffier B, Lepage E, Briere J, Herbrecht R, Tilly H, Bouabdallah R, Morel P, Van Den Neste E, Salles G, Gaulard P, Reyes F, Lederlin P, Gisselbrecht C. CHOP chemotherapy plus rituximab compared with CHOP alone in elderly patients with diffuse large-B-cell lymphoma. The N. Eng. J. Med 2002;346:235-242.

Coiffier B, Lepretre S, Pedersen LM, Gadeberg O, Fredriksen H, van Oers MH, Wooldridge J, Kloczko J, Holowiecki J, Hellmann A, Walewski J, Flensburg M, Petersen J, Robak T. Safety and efficacy of ofatumumab, a fully human monoclonal anti-CD20 antibody, in patients with relapsed or refractory B-cell chronic lymphocytic leukemia: a phase 1-2 study. Blood 2008;111:1094-1100. [PubMed: 18003886]

Coley WB. The treatment of malignant tumors by repeated inoculations of erysipelas. With a report of ten original cases. 1893. Clin. Orthop. Relat. Res 1991:3-11. [PubMed: 1984929]

Cooley S, Trachtenberg E, Bergemann TL, Saeteurn K, Klein J, Le CT, Marsh SG, Guethlein LA, Parham P, Miller JS, Weisdorf DJ. Donors with group B KIR haplotypes improve relapse-free survival after unrelated hematopoietic cell transplantation for acute myelogenous leukemia. Blood 2009;113:726732. [PubMed: 18945962]

Cooley S, Xiao F, Pitt M, Gleason M, McCullar V, Bergemann TL, McQueen KL, Guethlein LA, Parham $\mathrm{P}$, Miller JS. A subpopulation of human peripheral blood NK cells that lacks inhibitory receptors for self-MHC is developmentally immature. Blood 2007;110:578-586. [PubMed: 17392508]

Cragg MS, Morgan SM, Chan HTC, Morgan BP, Filatov AV, Johnson PWM, French RR, Glennie MJ. Complement-mediated lysis by anti-CD20 mAb correlates with segregation into lipid 'rafts'. Blood 2002;101:1045-1052. [PubMed: 12393541]

Cunningham D, Humblet Y, Siena S, Khayat D, Bleiberg H, Santoro A, Bets D, Mueser M, Harstrick A, Verslype C, Chau I, Van Cutsem E. Cetuximab monotherapy and cetuximab plus irinotecan in irinotecan-refractory metastatic colorectal cancer. N. Engl. J. Med 2004;351:337-345. [PubMed: 15269313]

Curti BD, Ochoa AC, Powers GC, Kopp WC, Alvord WG, Janik JE, Gause BL, Dunn B, Kopreski MS, Fenton R, Zea A, Dansky-Ullmann C, Strobl S, Harvey L, Nelson E, Sznol M, Longo DL. Phase I trial of anti-CD3-stimulated CD4+ T cells, infusional interleukin-2, and cyclophosphamide in patients with advanced cancer. J. Clin. Oncol 1998;16:2752-2760. [PubMed: 9704728]

Czuczman M, Thall A, Witzig TE, Vose JM, Younes A, Emmanouilides C, Miller TP, Moore JO, Leonard JP, Gordon LI, Sweetenham J, Alkuzweny B, Finucane DM, Leigh BR. Phase I/II study of galiximab, an anti-CD80 antibody, for relapsed or refractory follicular lymphoma. J. Clin. Oncol 2005;233:4390-4398. [PubMed: 15994148] 
D'Adamo DR, Anderson SE, Albritton K, Yamada J, Riedel E, Scheu K, Schwartz GK, Chen H, Maki RG. Phase II study of doxorubicin and bevacizumab for patients with metastatic soft-tissue sarcomas. J. Clin. Oncol 2005;23:7135-7142. [PubMed: 16192597]

Dang N, Hagemeister FB, Pro B, McLaughlin P, Romaguera JE, Jones D, Samuels B, Samaniego F, Younes A, Wang M, Goy A, Rodriguez MA, Walker PL, Arredondo Y, Tong AT, Fayad L. Phase II study of denileukin diftitox for relapsed/refractory B-Cell non-Hodgkin's lymphoma. J. Clin. Oncol 2004;22:4095-4102. [PubMed: 15353540]

Dang N, Pro B, Hagemeister FB, Samaniego F, Jones D, Samuels BI, Rodriguez MA, Goy A, Romaguera JE, McLaughlin P, Tong AT, Turturro F, Walker PL, Fayad L. Phase II trial of denileukin diftitox for relapsed/refractory T-cell non-Hodgkin lymphoma. Br. J. Haematol 2007;6:439-447. [PubMed: 17233846]

Davies A. Radioimmunotherapy for B-cell lymphoma: Y90 ibritumomab tiuxetan and I(131) tositumomab. Oncogene 2007;26:3614-3628. [PubMed: 17530015]

Davies SM, Ruggieri L, DeFor T, Wagner JE, Weisdorf DJ, Miller JS, Velardi A, Blazar BR. Evaluation of KIR ligand incompatibility in mismatched unrelated donor hematopoietic transplants. Killer immunoglobulin-like receptor. Blood 2002;100:3825-3827. [PubMed: 12393440]

Davis-Smyth T, Chen H, Park J, Presta LG, Ferrara N. The second immunoglobulin-like domain of the VEGF tyrosine kinase receptor Flt-1 determines ligand binding and may initiate a signal transduction cascade. Embo J 1996;15:4919-4927. [PubMed: 8890165]

Deans JP, Li H, Polyak MJ. CD20-mediated apoptosis: signalling through lipid rafts. Immunology 2002;107:176-182. [PubMed: 12383196]

Deans JP, Robbins SM, Polyak MJ, Savage JA. Rapid redistribution of CD20 to a low density detergentinsoluble membrane compartment. J. Biol. Chem 1998;273:344-348. [PubMed: 9417086]

Demko S, Summers J, Keegan P, Pazdur R. FDA Drug approval summary: alemtuzumab as singel agent treatment for B cell CLL. Oncologist 2008;13:167-174. [PubMed: 18305062]

Di Gaetano N, Xiao Y, Erba E, Bassan R, Rambaldi A, Golay J, Introna M. Synergism between fludarabine and rituximab revealed in a follicular lymphoma cell line resistant to the cytotoxic activity of either drug alone. Br. J. Haematol 2001;114:800-809. [PubMed: 11564066]

Disis ML, Bernhard H, Jaffee EM. Use of tumour-responsive T cells as cancer treatment. Lancet 2009;373:673-683. [PubMed: 19231634]

Ernst LK, Metes D, Herberman RB, Morel PA. Allelic polymorphisms in the FcgammaRIIC gene can influence its function on normal human natural killer cells. J. Mol. Med 2002;80:248-257. [PubMed: 11976734]

Farag SS, Bacigalupo A, Eapen M, Hurley C, Dupont B, Caligiuri MA, Boudreau C, Nelson G, Oudshoorn M, van Rood J, Velardi A, Maiers M, Setterholm M, Confer D, Posch PE, Anasetti C, Kamani N, Miller JS, Weisdorf D, Davies SM. The effect of KIR ligand incompatibility on the outcome of unrelated donor transplantation: a report from the center for international blood and marrow transplant research, the European blood and marrow transplant registry, and the Dutch registry. Biol. Blood Marrow Transplant 2006;12:876-884. [PubMed: 16864058]

Fayad L, Patel H, Verhoef G, Czuczman M, Foran J, Gine E, Rohatiner A, Smith MR, Shapiro M, Advani A. Clinical Activity of the Immunoconjugate CMC-544 in B-Cell Malignancies: Preliminary Report of the Expanded Maximum Tolerated Dose (MTD) Cohort of a Phase 1 Study. Blood 2006;108:A2711.

Ferrara N, Davis-Smyth T. The biology of vascular endothelial growth factor. Endocr. Rev 1997;18:425. [PubMed: 9034784]

Ferrara TA, Hodge JW, Gulley JL. Combining radiation and immunotherapy for synergistic antitumor therapy. Curr. Opin. Mol. Ther 2009;11:37-42. [PubMed: 19169958]

Fisher R, Kaminski MS, Wahl RL, Knox SJ, Zelenetz AD, Vose JM, Leonard JP, Kroll S, Goldsmith SJ, Coleman M. Tositumomab and iodine-131 tositumomab produces durable complete remissions in a subset of heavily pretreated patients with low-grade and transformed non-Hodgkin's lymphomas. J. Clin. Oncol 2005;23:7565-7573. [PubMed: 16186600]

Fong L, Small EJ. Anti-cytotoxic T-lymphocyte antigen-4 antibody: the first in an emerging class of immunomodulatory antibodies for cancer treatment. J. Clin. Oncol 2008;26:5275-5283. [PubMed: 18838703] 
Friedberg JW, Neuberg D, Gribben JG, Fisher DC, Canning C, Koval M, Poor CM, Green LM, Daley J, Soiffer R, Ritz J, Freedman AS. Combination immunotherapy with rituximab and interleukin 2 in patients with relapsed or refractory follicular non-Hodgkin's lymphoma. Br. J. Haematol 2002;117:828-834. [PubMed: 12060117]

Garay RP, Viens P, Bauer J, Normier G, Bardou M, Jeannin JF, Chiavaroli C. Cancer relapse under chemotherapy: why TLR2/4 receptor agonists can help. Eur. J. Pharmacol 2007;563:1-17. [PubMed: 17383632]

Giebel S, Locatelli F, Lamparelli T, Velardi A, Davies S, Frumento G, Maccario R, Bonetti F, Wojnar J, Martinetti M, Frassoni F, Giorgiani G, Bacigalupo A, Holowiecki J. Survival advantage with KIR ligand incompatibility in hematopoietic stem cell transplantation from unrelated donors. Blood 2003;102:814-819. [PubMed: 12689936]

Golay J, Lazzari M, Facchinetti V, Bernasconi S, Borleri G, Barbui T. CD20 levels determine the in vitro susceptibility to rituximab and complement of B-cell chronic lymphocytic leukemia: further regulation by CD55 and CD59. Blood 2001;98:3383-3389. [PubMed: 11719378]

Golay J, Zaffaroni L, Vaccari T. Biologic response of B lymphoma cells to anti-CD20 monoclonal antibody rituximab in vitro: CD55 and CD59 regulate complement-mediated cell lysis. Blood 2000;95:3900-3908. [PubMed: 10845926]

Goldenberg D, Rossi EA, Sharkey RM, McBride WJ, Chang CH. Multifunctional antibodies by the Dockand-Lock method for improved cancer imaging and therapy by pretargeting. J. Nucl. Med 2008;49:158-163. [PubMed: 18077530]

Gopal A, Rajendran JG, Gooley TA, Pagel JM, Fisher DR, Petersdorf SH, Maloney DG, Eary JF, Appelbaum FR, Press OW. High-dose [131I] tositumomab (anti-CD20) radioimmunotherapy and autologous hematopoietic stem-cell transplantation for adults $>$ or $=60$ years old with relapsed or refractory B-cell lymphoma. J. Clin. Oncol 2007;25:1396-1402. [PubMed: 17312330]

Greenwald RJ, Freeman GJ, Sharpe AH. The B7 family revisited. Annu Rev Immunol 2005;23:515-548. [PubMed: 15771580]

Griffith TS, Rauch CT, Smolak Pam J. Waugh Jennifer Y. Boiani N, L. David H, Smith CA, Goodwin RG, Kubin MZ. Functional Analysis of TRAIL Receptors Using Monoclonal Antibodies. J. Immunol 1999;162:1597-2605. [PubMed: 9973418]

Grillo-Lopez AJ. Rituximab: an insider's historical perspective. Semin. Oncol 2000;27:9-16. [PubMed: 11226006]

Grossbard M, Multani PS, Freedman AS, O'Day S, Gribben JG, Rhuda C, Neuberg D, Nadler LM. A Phase II study of adjuvant therapy with anti-B4-blocked ricin after autologous bone marrow transplantation for patients with relapsed B-cell non-Hodgkin's lymphoma. Clin. Cancer Res 1999;5:2392-2398. [PubMed: 10499609]

Habermann TM, Weller EA, Morrison VA, Gascoyne RD, Cassileth PA, Cohn JB, Dakhil SR, Woda B, Fisher RI, Peterson BA, Horning SJ. Rituximab-CHOP versus CHOP alone or with maintenance rituximab in older patients with diffuse large B-cell lymphoma. J. Clin. Oncol 2006;24:3121-3127. [PubMed: 16754935]

Hayes RJ, Bentzien J, Ary ML, Hwang MY, Jacinto JM, Vielmetter J, Kundu A, Dahiyat BI. Combining computational and experimental screening for rapid optimization of protein properties. Proc. Natl. Acad. Sci. U.S.A 2002;99:15926-15931. [PubMed: 12446841]

Hochster H, Weller E, Gascoyne RD, Habermann TM, Gordon LI, Ryan T, Zhang L, Colocci N, Frankel S, Horning SJ. Maintenance rituximab after cyclophosphamide, vincristine, and prednisone prolongs progression-free survival in advanced indolent lymphoma: results of the randomized phase III ECOG1496 Study. J. Clin. Oncol 2009;27:1607-1614. [PubMed: 19255334]

Hoogenboom HR. Overview of antibody phage-display technology and its applications. Methods Mol. Biol 2002;178:1-37. [PubMed: 11968478]

Hooijberg E, Sein JJ, van den Berk PCM, Hart AAM, van der Valk MA, Kast WM, Melief CJM, Hekman A. Eradication of Large Human B Cell Tumors in Nude Mice with Unconjugated CD20 Monoclonal Antibodies and Interleukin 2. Cancer Res 1995;55:2627-2634. [PubMed: 7540106]

Horning S, Younes A, Jain V, Kroll S, Lucas J, Podoloff D, Goris M. Efficacy and safety of tositumomab and iodine-131 tositumomab (Bexxar) in B-cell lymphoma, progressive after rituximab. J. Clin. Oncol 2005;23:712-719. [PubMed: 15613695] 
Hsu KC, Gooley T, Malkki M, Pinto-Agnello C, Dupont B, Bignon JD, Bornhauser M, Christiansen F, Gratwohl A, Morishima Y, Oudshoorn M, Ringden O, van Rood JJ, Petersdorf E. KIR ligands and prediction of relapse after unrelated donor hematopoietic cell transplantation for hematologic malignancy. Biol. Blood Marrow Transplant 2006;12:828-836. [PubMed: 16864053]

Hsu KC, Keever-Taylor CA, Wilton A, Pinto C, Heller G, Arkun K, O'Reilly RJ, Horowitz MM, Dupont B. Improved outcome in HLA-identical sibling hematopoietic stem-cell transplantation for acute myelogenous leukemia predicted by KIR and HLA genotypes. Blood 2005;105:4878-4884. [PubMed: 15731175]

Hudson ME, Pozdnyakova I, Haines K, Mor G, Snyder M. Identification of differentially expressed proteins in ovarian cancer using high-density protein microarrays. Proc. Natl. Acad. Sci. U.S.A 2007;104:17494-17499. [PubMed: 17954908]

Hurwitz H, Fehrenbacher L, Novotny W, Cartwright T, Hainsworth J, Heim W, Berlin J, Baron A, Griffing S, Holmgren E, Ferrara N, Fyfe G, Rogers B, Ross R, Kabbinavar F. Bevacizumab plus irinotecan, fluorouracil, and leucovorin for metastatic colorectal cancer. N. Engl. J. Med 2004;350:2335-2342. [PubMed: 15175435]

Hurwitz HI, Fehrenbacher L, Hainsworth JD, Heim W, Berlin J, Holmgren E, Hambleton J, Novotny WF, Kabbinavar F. Bevacizumab in combination with fluorouracil and leucovorin: an active regimen for first-line metastatic colorectal cancer. J. Clin. Oncol 2005;23:3502-3508. [PubMed: 15908660]

Iannello A, Ahmad A. Role of antibody-dependent cell-mediated cytotoxicity in the efficacy of therapeutic anti-cancer monoclonal antibodies. Cancer Metastasis Rev 2005;24:487-499. [PubMed: 16408158]

Irving RA, Coia G, Roberts A, Nuttall SD, Hudson PJ. Ribosome display and affinity maturation: from antibodies to single $\mathrm{V}$-domains and steps towards cancer therapeutics. J. Immunol. Methods 2001;248:31-45. [PubMed: 11223067]

Jacene H, Filice R, Kasecamp W, Wahl RL. Comparison of 90Y-ibritumomab tiuxetan and 131Itositumomab in clinical practice. J. Nucl. Med 2007;48:1767-1776. [PubMed: 17942813]

Jager D. Potential target antigens for immunotherapy identified by serological expression cloning (SEREX). Methods Mol. Biol 2007;360:319-326. [PubMed: 17172736]

Jahrsdorfer B, Weiner GJ. CpG oligodeoxynucleotides as immunotherapy in cancer. Update Cancer Ther 2008;3:27-32. [PubMed: 19255607]

Kaminski M, Tuck M, Estes J, Kolstad A, Ross CW, Zasadny K, Regan D, Kison P, Fisher S, Kroll S, Wahl RL. 131I-tositumomab therapy as initial treatment for follicular lymphoma. N. Engl. J. Med 2005;352:441-449. [PubMed: 15689582]

Kaufmann H, Raderer M, Wöhrer S, Püspök A, Bankier A, Zielinski C, Chott A, Drach J. Antitumor activity of rituximab plus thalidomide in patients with relapsed/refractory mantle cell lymphoma. Blood 2004;104:2269-2271. [PubMed: 15166030]

Kavanagh B, O'Brien S, Lee D, Hou Y, Weinberg V, Rini B, Allison JP, Small EJ, Fong L. CTLA4 blockade expands FoxP3+ regulatory and activated effector CD4+ T cells in a dose-dependent fashion. Blood 2008;112:1175-1183. [PubMed: 18523152]

Keating M, Cazin B, Coutré S, Birhiray R, Kovacsovics T, Langer W, Leber B, Maughan T, Rai K, Tjønnfjord G, Bekradda M, Itzhaki M, Hérait P. Campath-1H treatment of T-cell prolymphocytic leukemia in patients for whom at least one prior chemotherapy regimen has failed. J. Clin.Oncol 2002;20:205-213. [PubMed: 11773171]

Kennedy AD, Solga MD, Schuman TA, Chi AW, Lindorfer MA, Sutherland WM, Foley PL, Taylor RP. An anti-C3b(i) mAb enhances complement activation, C3b(i) deposition, and killing of CD20 ${ }^{+}$cells by rituximab. Blood 2003;101:1071-1079. [PubMed: 12393727]

Khan K, Emmanouilides C, Benson DM Jr. Hurst D, Garcia P, Michelson G, Milan S, Ferketich AK, Piro L, Leonard JP, Porcu P, Eisenbeis CF, Banks AL, Chen L, Byrd JC, Caligiuri MA. A phase 2 study of rituximab in combination with recombinant interleukin-2 for rituximab-refractory indolent non-Hodgkin's lymphoma. Clin. Cancer Res 2006;12:7046-7053. [PubMed: 17145827]

Khazaeli MB, Conry RM, LoBuglio AF. Human immune response to monoclonal antibodies. J. Immunother 1994;15:42-52.

Kim JA. Targeted therapies for the treatment of cancer. Am. J. Surg 2003;186:264-268. [PubMed: 12946830] 
Klingemann HG, Martinson J. Ex vivo expansion of natural killer cells for clinical applications. Cytotherapy 2004;6:15-22. [PubMed: 14985163]

Kohler G, Milstein C. Continuous cultures of fused cells secreting antibody of predefined specificity. Nature 1975;256:495-497. [PubMed: 1172191]

Kohler G, Milstein C. Derivation of specific antibody-producing tissue culture and tumor lines by cell fusion. Eur. J. Immunol 1976;6:511-519. [PubMed: 825377]

Korman A, Yellin M, Keler T. Tumor immunotherapy: preclinical and clinical activity of anti-CTLA4 antibodies. Curr. Opin. Investig. Drugs 2005;6:582-591.

Korman AJ, Peggs KS, Allison JP. Checkpoint blockade in cancer immunotherapy. Adv. Immunol 2006;90:297-339. [PubMed: 16730267]

Kreitman R, Wilson WH, Bergeron K, Raggio M, Stetler-Stevenson M, FitzGerald DJ, Pastan I. Efficacy of the anti-CD22 recombinant immunotoxin BL22 in chemotherapy-resistant hairy-cell leukemia. N. Engl. J. Med 2001;345:241-247. [PubMed: 11474661]

Kreitman R, Wilson WH, White JD, Stetler-Stevenson M, Jaffe ES, Giardina S, Waldmann TA, Pastan I. Phase I trial of recombinant immunotoxin anti-Tac(Fv)-PE38 (LMB-2) in patients with hematologic malignancies. J. Clin. Oncol 2000;18:1622-1636. [PubMed: 10764422]

Krishnan A, Nademanee A, Fung HC, Raubitschek AA, Molina A, Yamauchi D, Rodriguez R, Spielberger RT, Falk P, Palmer JM, Forman SJ. Phase II trial of a transplantation regimen of yttrium-90 ibritumomab tiuxetan and high-dose chemotherapy in patients with non-Hodgkin's lymphoma. J. Clin. Oncol 2008;26:90-95. [PubMed: 18025438]

Kuwabara K, Nishishita T, Morishita M, Oyaizu N, Yamashita S, Kanematsu T, Obara T, Mimura Y, Inoue Y, Kaminishi M, Kaga K, Amino N, Kitaoka M, Ito K, Miyauchi A, Noguchi S, Uchimaru K, Akagawa E, Watanabe N, Takahashi TA, Sato K, Inazawa T, Nakaoka T, Yamashita N. Results of a phase I clinical study using dendritic cell vaccinations for thyroid cancer. Thyroid 2007;17:5358. [PubMed: 17274750]

Leonard J, Coleman M, Kostakoglu L, Chadburn A, Cesarman E, Furman RR, Schuster MW, Niesvizky R, Muss D, Fiore J, Kroll S, Tidmarsh G, Vallabhajosula S, Goldsmith SJ. Abbreviated chemotherapy with fludarabine followed by tositumomab and iodine I-131 tositumomab for untreated follicular lymphoma. J. Clin. Oncol 2005;23:5696. [PubMed: 16110029]

Leonard J, Friedberg JW, Younes A, Fisher D, Gordon LI, Moore J, Czuczman M, Miller T, Stiff P, Cheson BD, Forero-Torres A, Chieffo N, McKinney B, Finucane D, Molina A. A phase I/II study of galiximab (an anti-CD80 monoclonal antibody) in combination with rituximab for relapsed or refractory, follicular lymphoma. Annals Oncol 2007;18:1216-1223.

Leonard JP, Coleman M, Ketas J, Ashe M, Fiore JM, Furman RR, Niesvizky R, Shore T, C.A. Horne H, Kovacs J, Ding CL, Wegener WA, Horak ID, Goldenberg DM. Combination antibody therapy with epratuzumab and rituximab in relapsed or refractory non-Hodgkin's lymphoma. J. Clin. Oncol 2005;233:5044-5051. [PubMed: 15955901]

Leonard JP, Coleman M, Ketas JC, Chadburn A, Furman R, Schuster MW, Feldman EJ, Ashe M, S.S. Wegener WA, Hansen HJ, Ziccardi H, Eschenberg M, Gayko U, Fields SZ, C.A. Goldenberg DM. Epratuzumab, a humanized anti-CD22 antibody, in aggressive non-Hodgkin's lymphoma: phase I/ II clinical trial results. Clin. Cancer Res 2004;10:5327-5334. [PubMed: 15328168]

Leung W, Iyengar R, Turner V, Lang P, Bader P, Conn P, Niethammer D, Handgretinger R. Determinants of antileukemia effects of allogeneic NK cells. J. Immunol 2004;172:644-650. [PubMed: 14688377]

Lindén O, Hindorf C, Cavallin-Ståhl E, Wegener WA, Goldenberg DM, Horne H, Ohlsson T, Stenberg L, Strand SE, Tennvall J. Dose-fractionated radioimmunotherapy in non-Hodgkin's lymphoma using DOTA-conjugated, 90Y-radiolabeled, humanized anti-CD22 monoclonal antibody, epratuzumab. Clin. Cancer Res 2005;11:5215-5222. [PubMed: 16033839]

Lockhart C, Berlin JD. The epidermal growth factor receptor as a target for colorectal cancer therapy. Semin. Oncol 2005;32:52-60. [PubMed: 15726506]

Manches O, Lui G, Chaperot L, Gressin R, Molens J-P, Jacob MC, Sotto J-J, Lerous D, Bens J-C, Plumas J. In Vitro Mechanisms of Action of Rituximab on Primary Non-Hodgkin's Lymphomas. Blood 2002;101:949-954. [PubMed: 12393572] 
Marcus R, Imrie K, Belch A, Cunningham D, Flores E, Catalano J, Solal-Celigny P, Offner F, Walewski J, Raposo J, Jack A, Smith P. CVP chemotherapy plus rituximab compared with CVP as first-line treatment for advanced follicular lymphoma. Blood 2005;105:1417-1423. [PubMed: 15494430]

Mathas S, Rickers A, Bommert K, Dorken B, Mapara MY. Anti-CD20- and B-cell Receptor-mediated Apoptosis: Evidence for Shared Intracellular Signaling Pathways. Cancer Res 2000;60:7170-7176. [PubMed: 11156427]

McLaughlin P, Grillo-Lopez AJ, Link BK, Levy R, Czuczman MS, Williams ME, Heyman MR, BenceBruckler I, White CA, Cabanillas F, Jain V, Ho AD, Lister J, Wey K, Shen D, Dallaire BK. Rituximab chimeric anti-CD20 monoclonal antibody therapy for relapsed indolent lymphoma: half of patients respond to a four-dose treatment program. J. Clin. Oncol 1998;16:2825-2833. [PubMed: 9704735]

Melero I, Shuford WW, Newby SA, Aruffo A, Ledbetter JA, Hellstrom KE, Mittler RS, Chen L. Monoclonal antibodies against the 4-1BB T-cell activation molecule eradicate established tumors. Nat. Med 1997;3:682-685. [PubMed: 9176498]

Melief CJ. Cancer immunotherapy by dendritic cells. Immunity 2008;29:372-383. [PubMed: 18799145]

Messa C, Russo F, Caruso MG, Di Leo A. EGF, TGF-alpha, and EGF-R in human colorectal adenocarcinoma. Acta Oncol 1998;37:285-289. [PubMed: 9677101]

Metes D, Gambotto AA, Nellis J, Ruscin A, Stewart-Akers AM, Morel PA, Rao AS. Identification of the CD32/FcgammaRIIc-Q13/STP13 polymorphism using an allele-specific restriction enzyme digestion assay. J. Immunol. Methods 2001;258:85-95. [PubMed: 11684126]

Miller JS, Cooley S, Parham P, Farag SS, Verneris MR, McQueen KL, Guethlein LA, Trachtenberg EA, Haagenson M, Horowitz MM, Klein JP, Weisdorf DJ. Missing KIR ligands are associated with less relapse and increased graft-versus-host disease (GVHD) following unrelated donor allogeneic HCT. Blood 2007a;109:5058-5061. [PubMed: 17317850]

Miller JS, Soignier Y, Panoskaltsis-Mortari A, McNearney SA, Yun GH, Fautsch SK, McKenna D, Le C, Defor TE, Burns LJ, Orchard PJ, Blazar BR, Wagner JE, Slungaard A, Weisdorf DJ, Okazaki IJ, McGlave PB. Successful adoptive transfer and in vivo expansion of human haploidentical NK cells in patients with cancer. Blood 2005;105:3051-3057. [PubMed: 15632206]

Miller K, Wang M, Gralow J, Dickler M, Cobleigh M, Perez EA, Shenkier T, Cella D, Davidson NE. Paclitaxel plus bevacizumab versus paclitaxel alone for metastatic breast cancer. N. Engl. J. Med 2007;357:2666-2676. [PubMed: 18160686]

Miller KD, Chap LI, Holmes FA, Cobleigh MA, Marcom PK, Fehrenbacher L, Dickler M, Overmoyer BA, Reimann JD, Sing AP, Langmuir V, Rugo HS. Randomized phase III trial of capecitabine compared with bevacizumab plus capecitabine in patients with previously treated metastatic breast cancer. J. Clin. Oncol 2005;23:792-799. [PubMed: 15681523]

Miller RE, Jones J, Le T, Whitmore J, Boiani N, Gliniak B, Lynch DH. 4-1BB-specific monoclonal antibody promotes the generation of tumor-specific immune responses by direct activation of CD8 T cells in a CD40-dependent manner. J. Immunol 2002;169:1792-1800. [PubMed: 12165501]

Mirick GR, Bradt BM, Denardo SJ, Denardo GL. A review of human anti-globulin antibody (HAGA, HAMA, HACA, HAHA) responses to monoclonal antibodies. Not four letter words. Q J. Nucl. Med. Mol. Imaging 2004;48:251-257. [PubMed: 15640788]

Morel PA, Ernst LK, Metes D. Functional CD32 molecules on human NK cells. Leuk. Lymphoma 1999;35:47-56. [PubMed: 10512162]

Morgan RA, Dudley ME, Wunderlich JR, Hughes MS, Yang JC, Sherry RM, Royal RE, Topalian SL, Kammula US, Restifo NP, Zheng Z, Nahvi A, de Vries CR, Rogers-Freezer LJ, Mavroukakis SA, Rosenberg SA. Cancer regression in patients after transfer of genetically engineered lymphocytes. Science 2006;314:126-129. [PubMed: 16946036]

Nagayama H, Sato K, Morishita M, Uchimaru K, Oyaizu N, Inazawa T, Yamasaki T, Enomoto M, Nakaoka T, Nakamura T, Maekawa T, Yamamoto A, Shimada S, Saida T, Kawakami Y, Asano S, Tani K, Takahashi TA, Yamashita N. Results of a phase I clinical study using autologous tumour lysate-pulsed monocyte-derived mature dendritic cell vaccinations for stage IV malignant melanoma patients combined with low dose interleukin-2. Melanoma Res 2003;13:521-530. [PubMed: 14512794] 
Nam KO, Kang WJ, Kwon BS, Kim SJ, Lee HW. The therapeutic potential of 4-1BB (CD137) in cancer. Curr. Cancer Drug Targets 2005;5:357-363. [PubMed: 16101383]

Nguyen M, Marcellus RC, Roulston A, Watson M, Serfass L, Murthy Madiraju SR, Goulet D, Viallet J, Bélec L, Billot X, Acoca S, Purisima E, Wiegmans A, Cluse L, Johnstone RW, Beauparlant P, Shore GC. Small molecule obatoclax (GX15-070) antagonizes MCL-1 and overcomes MCL-1-mediated resistance to apoptosis. Proc. Natl. Acad. Sci. U.S.A 2007;104:19512-19517. [PubMed: 18040043]

Norton L, Slamon D, Leyland-Jones B. Overall survival (OS) advantage to simultaneous chemotherapy $(\mathrm{CRx})$ plus the humanized anti-HER2 monoclonal antibody $\operatorname{Herceptin}^{\mathrm{R}}(\mathrm{H})$ in HER2everexpressing (HER2+) metastatic breast cancer (MBC). Proc. Am. Soc. Clin. Oncol 1999:127a.

O'Hanlon LH. Natural born killers: NK cells drafted into the cancer fight. J. Natl. Cancer Inst 2004;96:651-653. [PubMed: 15126597]

O'Reilly MS, Holmgren L, Shing Y, Chen C, Rosenthal RA, Moses M, Lane WS, Cao Y, Sage EH, Folkman J. Angiostatin: a novel angiogenesis inhibitor that mediates the suppression of metastases by a Lewis lung carcinoma. Cell 1994;79:315-328. [PubMed: 7525077]

Oble DA, Loewe R, Yu P, Mihm MC Jr. Focus on TILs: prognostic significance of tumor infiltrating lymphocytes in human melanoma. Cancer Immun 2009;9:3. [PubMed: 19338264]

Paoluzzi L, Gonen M, Gardner JR, Mastrella J, Yang D, Holmlund J, Sorensen M, Leopold L, Manova K, Marcucci G, Heaney ML, O' Connor OA. Targeting Bcl-2 family members with the BH3 mimetic AT-101 markedly enhances the therapeutic effects of chemotherapeutic agents in in vitro and in vivo models of B-cell lymphoma. Blood 2008;111:5350-5358. [PubMed: 18292288]

Passweg JR, Stern M, Koehl U, Uharek L, Tichelli A. Use of natural killer cells in hematopoetic stem cell transplantation. Bone Marrow Transplant 2005;35:637-643. [PubMed: 15654351]

Pegram M, Lipton A, Hayes D, Weber B, Baselga J, Tripathy D, Baly D, Baughman S, Twassell T, Glaspy J, Slamon D. Phase II study of receptor-enhanced chemosensitivity using recombinant humanized anti-p185 $5^{\text {her2/neu }}$ monoclonal antibody plus cisplatin in patients with HER2/neu-overexpressing metastatic breast cancer refractory to chemotherapy treatment. J. Clin. Oncol 1998;16:2659-2671. [PubMed: 9704716]

Perez-Diez A, Joncker NT, Choi K, Chan WF, Anderson CC, Lantz O, Matzinger P. CD4 cells can be more efficient at tumor rejection than CD8 cells. Blood 2007;109:5346-5354. [PubMed: 17327412]

Pfreundschuh M, Trumper L, Osterborg A, Pettengell R, Trneny M, Imrie K, Ma D, Gill D, Walewski J, Zinzani PL, Stahel R, Kvaloy S, Shpilberg O, Jaeger U, Hansen M, Lehtinen T, Lopez-Guillermo A, Corrado C, Scheliga A, Milpied N, Mendila M, Rashford M, Kuhnt E, Loeffler M. CHOP-like chemotherapy plus rituximab versus $\mathrm{CHOP}$-like chemotherapy alone in young patients with goodprognosis diffuse large-B-cell lymphoma: a randomised controlled trial by the MabThera International Trial (MInT) Group. Lancet Oncol 2006;7:379-391. [PubMed: 16648042]

Pirker R, Pereira JR, Szczesna A, von Pawel J, Krzakowski M, Ramlau R, Vynnychenko I, Park K, Yu CT, Ganul V, Roh JK, Bajetta E, O'Byrne K, de Marinis F, Eberhardt W, Goddemeier T, Emig M, Gatzemeier U. Cetuximab plus chemotherapy in patients with advanced non-small-cell lung cancer (FLEX): an open-label randomised phase III trial. Lancet 2009;373:1525-1531. [PubMed: 19410716]

Pittet MJ. Behavior of immune players in the tumor microenvironment. Curr. Opin. Oncol 2009;21:5359. [PubMed: 19125019]

Press O, Unger JM, Braziel RM, Maloney DG, Miller TP, Leblanc M, Fisher RI. Phase II trial of CHOP chemotherapy followed by tositumomab/iodine I-131 tositumomab for previously untreated follicular non-Hodgkin's lymphoma: five-year follow-up of Southwest Oncology Group Protocol S9911. J. Clin. Oncol 2007;24:4143-4149. [PubMed: 16896003]

Presta LG, Chen H, O'Connor SJ, Chisholm V, Meng YG, Krummen L, Winkler M, Ferrara N. Humanization of an anti-vascular endothelial growth factor monoclonal antibody for the therapy of solid tumors and other disorders. Cancer Res 1997;57:4593-4599. [PubMed: 9377574]

Puri C, Tosoni D, Comai R, Rabellino A, Segat D, Caneva F, Luzzi P, Di Fiore PP, Tacchetti C. Relationships between EGFR signaling-competent and endocytosis-competent membrane microdomains. Mol. Biol. Cell 2005;16:2704-2718. [PubMed: 15772153]

Rafiq K, Bergtold A, Clynes R. Immune complex-mediated antigen presentation induces tumor immunity. J. Clin. Invest 2002;110:71-79. [PubMed: 12093890] 
Rakoff-Nahoum S, Medzhitov R. Toll-like receptors and cancer. Nat. Rev. Cancer 2009;9:57-63. [PubMed: 19052556]

Ramanarayanan J, Hernandez-Ilizaliturri FJ, Chanan-Khan A, Czuczman MS. Pro-apoptotic therapy with the oligonucleotide Genasense (oblimersen sodium) targeting Bcl-2 protein expression enhances the biological anti-tumour activity of rituximab. Br. J. Haematol 2004;127:519-530. [PubMed: 15566355]

Reddy N, Hernandez-Ilizaliturri FJ, Deeb G, Roth M, Vaughn M, Knight J, Wallace P, Czuczman MS. Immunomodulatory drugs stimulate natural killer-cell function, alter cytokine production by dendritic cells, and inhibit angiogenesis enhancing the anti-tumouractivity of rituximab in vivo. Br. J. Haematol 2008;140:36-45. [PubMed: 17995965]

Reff ME, Carner K, Chambers KS, Chinn PC, Leonard JE, Raab R, Newman RA, Hanna N, Anderson DR. Depletion of B cells in vivo by a chimeric mouse human monoclonal antibody to CD20. Blood 1994;83:435-445. [PubMed: 7506951]

Robert F, Ezekiel MP, Spencer SA, Meredith RF, Bonner JA, Khazaeli MB, Saleh MN, Carey D, LoBuglio AF, Wheeler RH, Cooper MR, Waksal HW. Phase I study of anti--epidermal growth factor receptor antibody cetuximab in combination with radiation therapy in patients with advanced head and neck cancer. J. Clin. Oncol 2001;19:3234-3243. [PubMed: 11432891]

Rogers LJ, Eva LJ, Luesley DM. Vaccines against cervical cancer. Curr. Opin. Oncol 2008;20:570-574. [PubMed: 19106663]

Romond EH, Perez EA, Bryant J, Suman VJ, Geyer CE Jr. Davidson NE, Tan-Chiu E, Martino S, Paik S, Kaufman PA, Swain SM, Pisansky TM, Fehrenbacher L, Kutteh LA, Vogel VG, Visscher DW, Yothers G, Jenkins RB, Brown AM, Dakhil SR, Mamounas EP, Lingle WL, Klein PM, Ingle JN, Wolmark N. Trastuzumab plus adjuvant chemotherapy for operable HER2-positive breast cancer. N. Engl. J. Med 2005;353:1673-1684. [PubMed: 16236738]

Ruggeri L, Capanni M, Urbani E, Perruccio K, Shlomchik WD, Tosti A, Posati S, Rogaia D, Frassoni F, Aversa F, Martelli MF, Velardi A. Effectiveness of donor natural killer cell alloreactivity in mismatched hematopoietic transplants. Science 2002;295:2097-2100. [PubMed: 11896281]

Salih HR, Goehlsdorf D, Steinle A. Release of MICB molecules by tumor cells: mechanism and soluble MICB in sera of cancer patients. Hum. Immunol 2006;67:188-195. [PubMed: 16698441]

Salih HR, Rammensee HG, Steinle A. Cutting edge: down-regulation of MICA on human tumors by proteolytic shedding. J. Immunol 2002;169:4098-4102. [PubMed: 12370336]

Saltz L, Rubin M, Hochster H. Cetuximab (IMC-C225) plus irinotecan (CPT-11) is active in CPT-11 refractory colorectal cancer (CRC) that expresses epidermal growth factor receptor (EGFR). A. Soc. Clin. Oncol. 2001

Saltz LB, Meropol NJ, Loehrer PJ Sr. Needle MN, Kopit J, Mayer RJ. Phase II trial of cetuximab in patients with refractory colorectal cancer that expresses the epidermal growth factor receptor. J. Clin. Oncol 2004;22:1201-1208. [PubMed: 14993230]

Sanderson K, Scotland R, Lee P, Liu D, Groshen S, Snively J, Sian S, Nichol G, Davis T, Keler T, Yellin M, Weber J. Autoimmunity in a phase I trial of a fully human anti-cytotoxic T-lymphocyte antigen-4 monoclonal antibody with multiple melanoma peptides and Montanide ISA 51 for patients with resected stages III and IV melanoma. J. Clin. Oncol 2005;23:741-750. [PubMed: 15613700]

Schultze JL, Anderson KC, Gilleece MH, Gribben JG, Nadler LM. A pilot study of combined immunotherapy with autologous adoptive tumour-specific T-cell transfer, vaccination with CD40activated malignant B cells and interleukin 2. Br. J. Haematol 2001;113:455-460. [PubMed: 11380416]

Sehn LH, Donaldson J, Chhanabhai M, Fitzgerald C, Gill K, Klasa R, MacPherson N, O'Reilly S, Spinelli JJ, Sutherland J, Wilson KS, Gascoyne RD, Connors JM. Introduction of combined CHOP plus rituximab therapy dramatically improved outcome of diffuse large B-cell lymphoma in British Columbia. J. Clin. Oncol 2005;23:5027-5033. [PubMed: 15955905]

Sigismund S, Woelk T, Puri C, Maspero E, Tacchetti C, Transidico P, Di Fiore PP, Polo S. Clathrinindependent endocytosis of ubiquitinated cargos. Proc. Natl. Acad. Sci. U.S.A 2005;102:2760 2765. [PubMed: 15701692]

Slamon D, Leyland-Jones B, Shak S, Fuchs H, Paton V, Bajamonde A, Fleming T, Eiermann W, Wolter J, Pegram M, Baselga J, Norton L. Use of chemotherapy plus a monoclonal antibody against HER2 
for metastatic breast cancer that overexpresses HER2. N. Engl. J. Med 2001;344:783-792.

[PubMed: 11248153]

Smith MR, Fang J, Joshi I. Enhanced efficacy of therapy with antisense BCL-2 oligonucleotides plus anti-CD20 monoclonal antibody in scid mouse/human lymphoma xenografts. Mol. Cancer Ther 2004;3:1693-1699. [PubMed: 15634664]

Smith MR, Zhang L, Gordon LI, Foran J, Kahl B, Gascoyne RD, Advani R, Paietta E, Weller E, Horning SJ. Phase II Study of R-CHOP Followed by 90Y-Ibritumomab Tiuxetan in Untreated Mantle Cell Lymphoma: Eastern Cooperative Oncology Group Study E1499. Blood 2007;110:A349.

Starlets D, Gore Y, Binsky I, Haran M, Harpaz N, Shvidel L, Becker-Herman S, Berrebi A, Shachar I. Cell surface CD74 initiates a signaling xascade leading to cell proliferation and survival. Blood 2006;107:4807-4816. [PubMed: 16484589]

Stein R, Mattes MJ, Cardillo TM, Hansen HJ, Chang C-H, Burton J, Govindan S, Goldenberg DM. CD74: A new candidatew target for immunotherapy of B cell neoplasms. Clin. Cancer Res 2007; 13:5556s5563s. [PubMed: 17875789]

Stein R, Qu Z, Chen S, Rosario A, Shi V, Hayes M, Horak ID, Hansen HJ, Goldenberg DM. Characterization of a new humanized anti-CD20 monoclonal antibody, IMMU-106, and its use in combination with the humanized anti-CD22 antibody, epratuzumab, for the therapy of nonHodgkin's lymphoma. Clin. Cancer Res 2004;15:2868-2878. [PubMed: 15102696]

Stein R, Smith MR, Chen S, Zalath M, Goldenberg DM. Combining milatuzumab with bortezomib, doxorubicin, or dexamethasone improves responses in multiple myeloma cell lines. Clin. Cancer Res 2009;15:2808-2817. [PubMed: 19351768]

Steplewski Z, Lubeck MD, Koprowski H. Human macrophages armed with murine immunoglobulin G2a antibodies to tumors destroy human cancer cells. Science 1983;221:865-867. [PubMed: 6879183]

Stone M, Sausville EA, Fay JW, Headlee D, Collins RH, Figg WD, Stetler-Stevenson M, Jain V, Jaffe ES, Solomon D, Lush RM, Senderowicz A, Ghetie V, Schindler J, Uhr JW, Vitetta ES. A phase I study of bolus versus continuous infusion of the anti-CD19 immunotoxin, IgG-HD37-dgA, in patients with B-cell lymphoma. Blood 1996;88:1188-1197. [PubMed: 8695836]

Strauss S, Morschhauser F, Rech J, Repp R, Solal-Celigny P, Zinzani PL, Engert A, Coiffier B, Hoelzer DF, Wegener WA, Teoh NK, Goldenberg DM, Lister TA. Multicenter phase II trial of immunotherapy with the humanized anti-CD22 antibody, epratuzumab, in combination with rituximab, in refractory or recurrent non-Hodgkin's lymphoma. J. Clin. Oncol 2006;24:3880-3886. [PubMed: 16864854]

Sznol M, H.F.S. Margolin K, McDermott DF, Ernstoff MS, Kirkwood JM, Wojtaszek C, Feltquate D, Logan T. Phase I study of BMS-663513, a fully human anti-CD137 agonist monoclonal antibody, in patients (pts) with advanced cancer. J. Clin. Oncol 2008;26:2008.(May 20 suppl; abstr 3007)

Trail PA, King HD, Dubowchik GM. Monoclonal antibody drug immunoconjugates for targeted treatment of cancer. Cancer Immunol. Immunother 2003;52:328-337. [PubMed: 12700948]

Uhrberg M, Valiante NM, Shum BP, Shilling HG, Lienert-Weidenbach K, Corliss B, Tyan D, Lanier LL, Parham P. Human diversity in killer cell inhibitory receptor genes. Immunity 1997;7:753-763. [PubMed: 9430221]

Umana P, Jean-Mairet J, Moudry R, Amstutz H, Bailey JE. Engineered glycoforms of an antineuroblastoma IgG1 with optimized antibody-dependent cellular cytotoxic activity. Nat. Biotechnol 1999;17:176-180. [PubMed: 10052355]

van Delft M, Wei AH, Mason KD, Vandenberg CJ, Chen L, Czabotar PE, Willis SN, Scott CL, Day CL, Cory S, Adams JM, Roberts AW, Huang DC. The BH3 mimetic ABT-737 targets selective Bcl-2 proteins and efficiently induces apoptosis via Bak/Bax if Mcl-1 is neutralized. Cancer Cell 2006;10:389-399. [PubMed: 17097561]

van der Kolk L, Grillo-López AJ, Baars JW, van Oers MH. Treatment of relapsed B-cell non-Hodgkin's lymphoma with a combination of chimeric anti-CD20 monoclonal antibodies (rituximab) and GCSF: final report on safety and efficacy. Leukemia 2003;17:1658-1664. [PubMed: 12886256]

Vilches C, Parham P. KIR: diverse, rapidly evolving receptors of innate and adaptive immunity. Annu. Rev. Immunol 2002;20:217-251. [PubMed: 11861603]

von Mehren M, Adams GP, Weiner LM. Monoclonal antibody therapy for cancer. Annu. Rev. Med 2003;54:343-369. [PubMed: 12525678] 
Vonderheide R, Flaherty KT, Khalil M, Stumacher MS, Bajor DL, Hutnick NA, Sullivan P, Mahany JJ, Gallagher M, Kramer A, Green SJ, O'Dwyer PJ, Running KL, Huhn RD, Antonia SJ. Clinical activity and immune modulation in cancer patients treated with CP-870,893, a novel CD40 agonist monoclonal antibody. J. Clin. Oncol 2007;25:876-883. [PubMed: 17327609]

Waldhauer I, Steinle A. Proteolytic release of soluble UL16-binding protein 2 from tumor cells. Cancer Res 2006;66:2520-2526. [PubMed: 16510567]

Wang X, Yu J, Sreekumar A, Varambally S, Shen R, Giacherio D, Mehra R, Montie JE, Pienta KJ, Sanda MG, Kantoff PW, Rubin MA, Wei JT, Ghosh D, Chinnaiyan AM. Autoantibody signatures in prostate cancer. N. Engl. J. Med 2005;353:1224-1235. [PubMed: 16177248]

Warren TL, Dahle CE, Weiner GJ. CpG oligodeoxynucleotides enhance monoclonal antibody therapy of a murine lymphoma. Clin. Lymphoma 2000;1:57-61. [PubMed: 11707814]

Weiner LM, Carter P. Tunable antibodies. Nat. Biotechnol 2005;23:556-557. [PubMed: 15877072]

Weng WK, Levy R. Two immunoglobulin G fragment C receptor polymorphisms independently predict response to rituximab in patients with follicular lymphoma. J. Clin. Oncol 2003;21:3940-3947. [PubMed: 12975461]

Wilcox RA, Flies DB, Zhu G, Johnson AJ, Tamada K, Chapoval AI, Strome SE, Pease LR, Chen L. Provision of antigen and CD137 signaling breaks immunological ignorance, promoting regression of poorly immunogenic tumors. J. Clin. Invest 2002;109:651-659. [PubMed: 11877473]

Witzig TE, Flinn IW, Gordon LI, Emmanouilides C, Czuczman MS, Saleh MN, Cripe L, Wiseman G, Olejnik T, Multani PS, White CA. Treatment with ibritumomab tiuxetan radioimmunotherapy in patients with rituximab-refractory follicular non-Hodgkin's lymphoma. J. Clin. Oncol 2002;20:3262-3269. [PubMed: 12149300]

Worn A, Pluckthun A. Stability engineering of antibody single-chain Fv fragments. J. Mol. Biol 2001;305:989-1010. [PubMed: 11162109]

Yamanaka R. Dendritic-cell- and peptide-based vaccination strategies for glioma. Neurosurg. Rev 2009;32:265-273. [PubMed: 19214609]

Yang XD, Jia XC, Corvalan JR, Wang P, Davis CG. Development of ABX-EGF, a fully human antiEGF receptor monoclonal antibody, for cancer therapy. Crit. Rev. Oncol. Hematol 2001;38:17-23. [PubMed: 11255078]

Younes A, Vose JM, Zelenetz AD, Smith MR, Burris H, Ansell S, Klein J, Kumm E, Czuczman M. Results of a Phase 2 Trial of HGS-ETR1 (Agonistic Human Monoclonal Antibody to TRAIL Receptor 1) in Subjects with Relapsed/Refractory Non-Hodgkin's Lymphoma. Blood 2005;106:A489.

Yu J, Venstrom JM, Liu XR, Pring J, Hasan RS, O'Reilly RJ, Hsu KC. Breaking tolerance to self, circulating natural killer cells expressing inhibitory KIR for non-self HLA exhibit effector function after T cell-depleted allogeneic hematopoietic cell transplantation. Blood 2009;113:3875-3884. [PubMed: 19179302] 


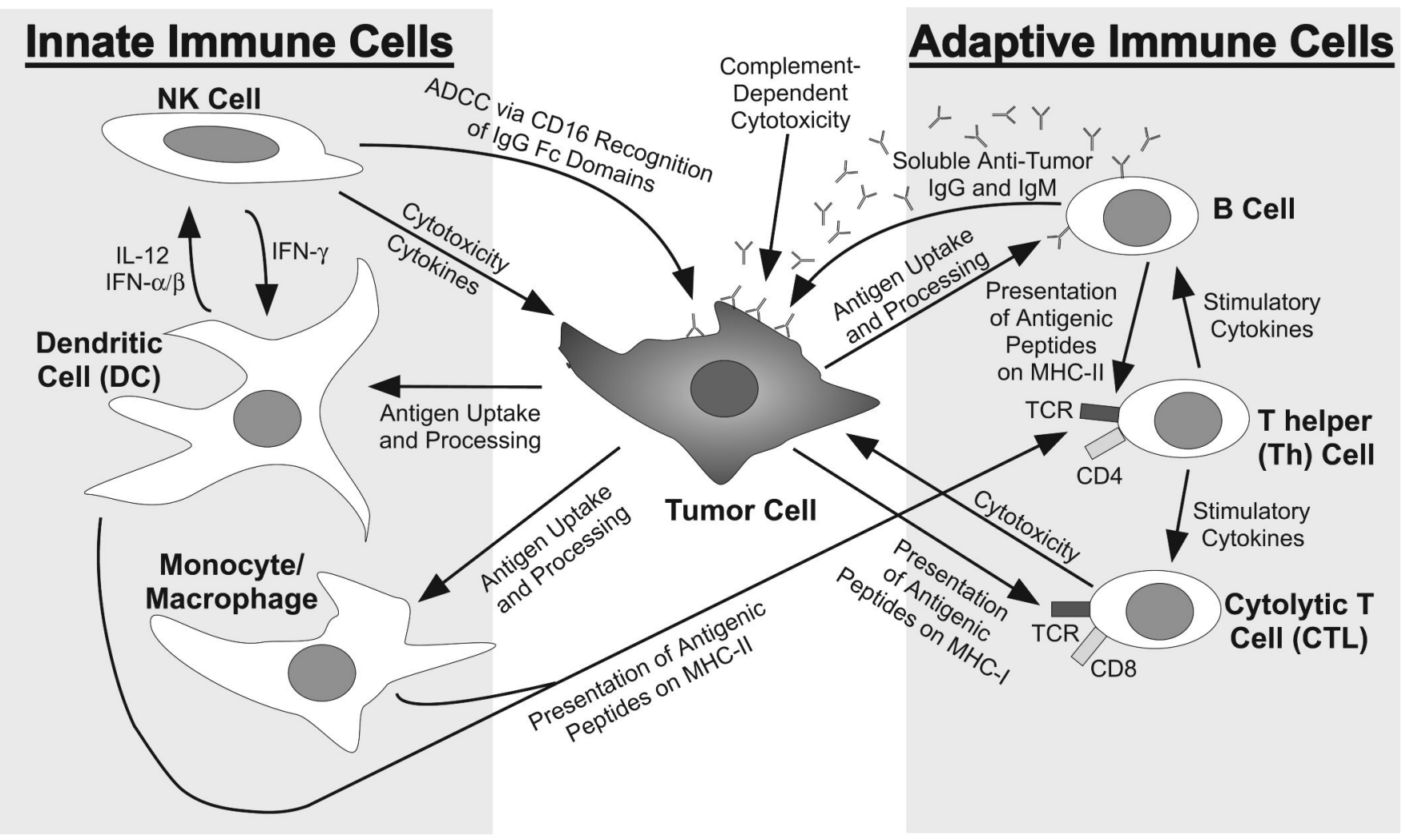

Figure 1. Major cells of the innate and adaptive immune systems and their functions in response to a tumor cell

Grey boxes delineate the major cell types constituting the innate and adaptive immune systems. Arrows describe impacts of immune cells on each other or the tumor. Note that this is a very basic schematic designed to define interactions of relevance to the review, and numerous complex molecular interactions and minor immune cell subsets further influence these functions. 

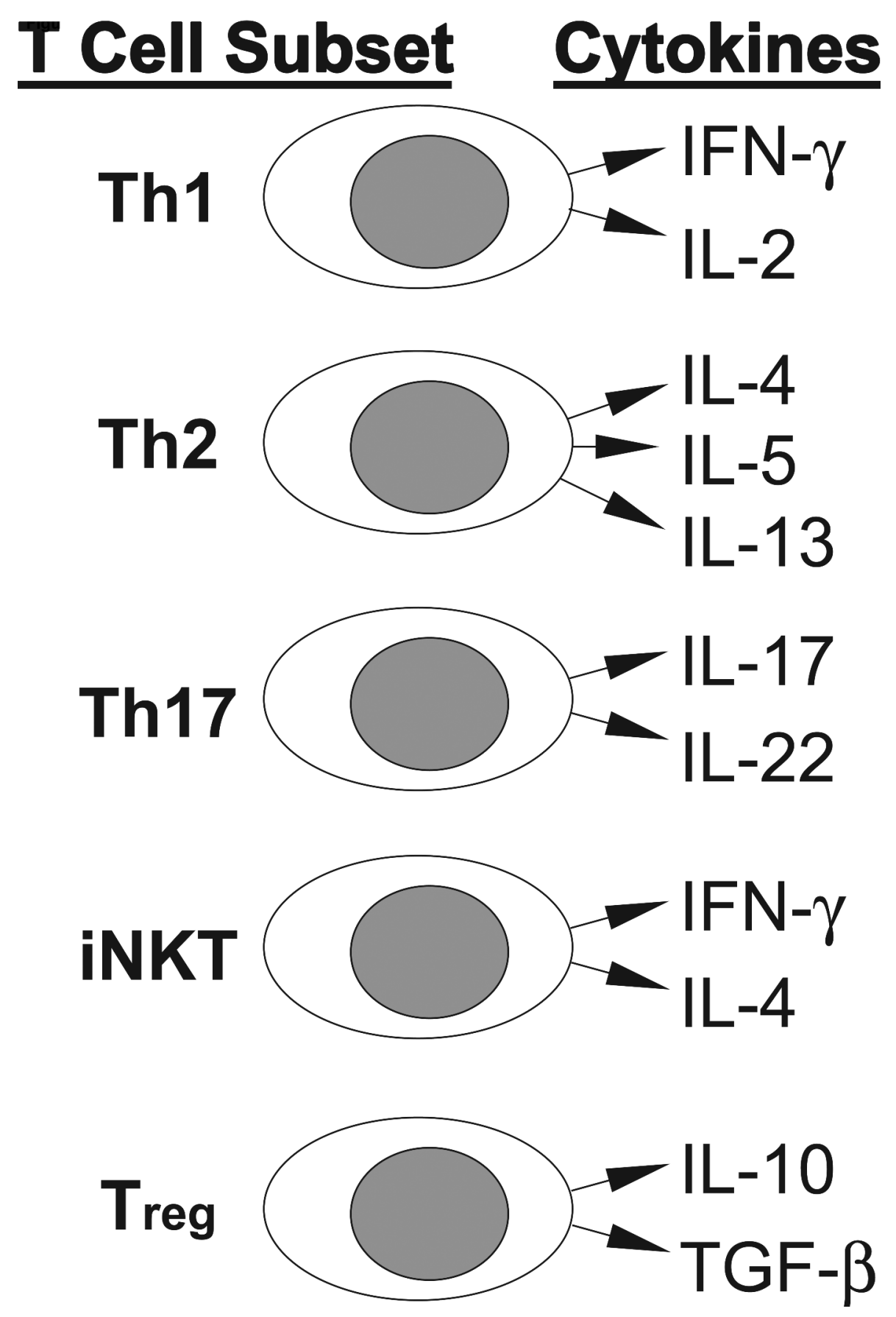

Figure 2. Minor subsets of $T$ cells and their cytokine products

Distinct $\mathrm{T}$ cell subsets are shown with the major cytokines that they can produce to influence other immune cells or tumors. 


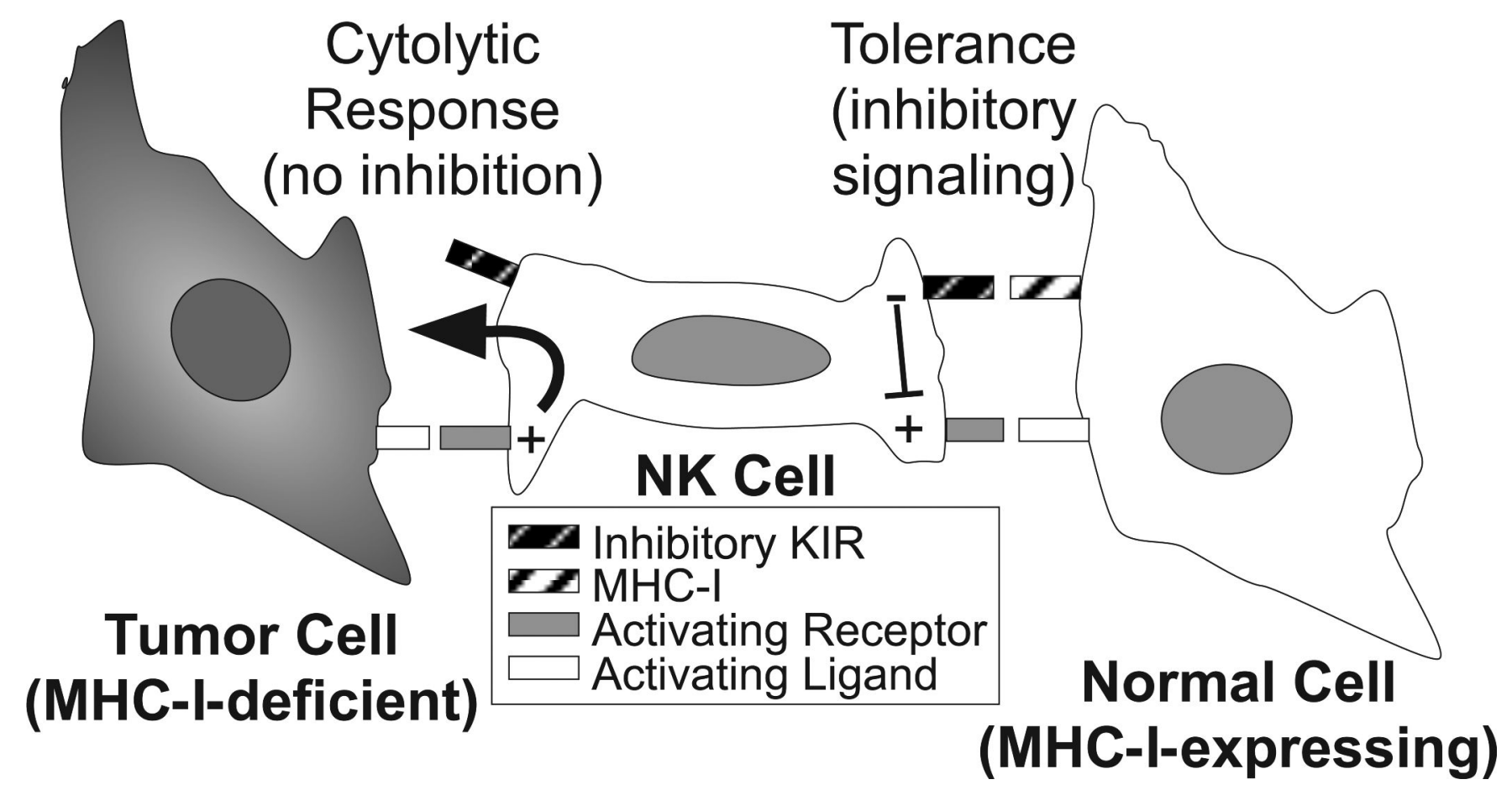

Figure 3. Surface receptor interactions establishing the basis for tolerance and cytolytic responses by NK cells

NK cell activation is regulated by a balance of signals derived from activating and inhibitory surface receptors. Activating receptors recognize an array of cell surface molecules, some of which are expressed ubiquitously on the surfaces of other cells of the body. Inhibitory receptors, such as KIR, recognize MHC class I (MHC-I) molecules, which are expressed on the surface of virtually every normal cell of the body, while many tumor cells lack expression of this "self" molecule. KIR engagement with MHC-I triggers inhibitory signals (predominantly protein tyrosine phosphatase-based) within the NK cell that dominantly suppress activating receptor signals (predominantly protein tyrosine kinase-based) and result in tolerance. Upon encounter with a rare tumor cell lacking MHC-I (so-called "missing self"), the lack of inhibitory signaling at the cell contact interface triggers rapid and directed release of cytolytic granules toward the tumor target cell, which results in specific cytolysis of the target cell. 
Table 1

Antibodies for Hematologic Malignancies

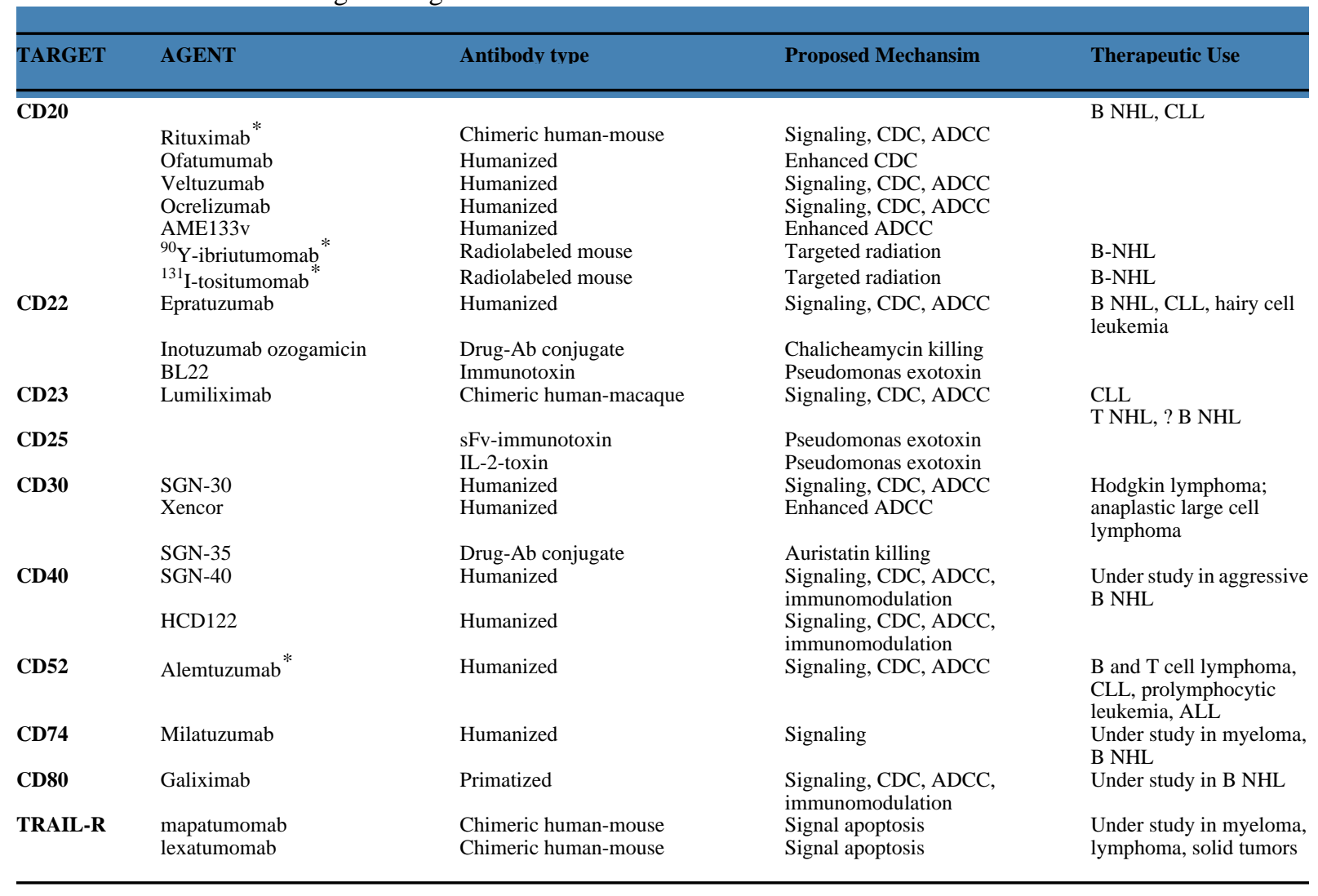

Indicates approved agents. Remainder are investigational. 
Table 2

Antibodies for Solid Tumors

\begin{tabular}{lllll}
\hline TARGET & AGENT & Antibody type & Proposed Mechansim & Therapeutic Use \\
\hline EGFR & Cetuximab & Chimeric & Signaling, ADCC & Head \& Neck, Colon \\
VEGF & Panitumomab & Fully Human & Signaling & GI \\
HER2/neu & Bevacizumab & Humanized & Ligand Binding & Breast, Lung, Colon \\
& Trastuzumab & Humanized & Signaling, ADCC & Breast \\
\hline
\end{tabular}

